\title{
Low-carbon advanced nanostructured steels: Microstructure, mechanical properties, and applications
}

\author{
Haojie Kong ${ }^{1}$, Zengbao $\mathrm{Jiao}^{2}$, Jian $\mathrm{Lu}^{1,4,5}$ and Chain Tsuan $\mathrm{Liu}^{1,3,4,5^{*}}$
}

\begin{abstract}
Low-carbon advanced nanostructured steels have been developed for various structural engineering applications, including bridges, automobiles, and other strength-critical applications such as the reactor pressure vessels in nuclear power stations. The mechanical performances and applications of these steels are strongly dependent on their microstructural features. By controlling the size, number density, distribution, and types of precipitates, it is possible to produce nanostructured steels with a tensile strength reaching as high as $2 \mathrm{GPa}$ while keeping a decent tensile elongation above $10 \%$ and a reduction of area as high as $40 \%$. Besides, through a careful control of strength contributions from multiple strengthening mechanisms, the nanostructured steels with superior strengths and low-temperature impact toughness can be obtained by avoiding the temper embrittlement regime. With appropriate $\mathrm{Mn}$ additions, these nanostructured steels can achieve a triple enhancement in ductility (total tensile elongation, TE of $\sim 30 \%$ ) at no expense of strengths (yield strength, YS of $\sim 1100$ to $1300 \mathrm{MPa}$, ultimate tensile strength, UTS of $\sim 1300$ to $1400 \mathrm{MPa}$ ). More importantly, these steels demonstrate good fabricability and weldability. In this paper, the microstructure-property relationships of these advanced nanostructured steels are comprehensively reviewed. In addition, the current limitations and future development of these nanostructured steels are carefully discussed and outlined.
\end{abstract}

Keywords: heterogeneous, nano-precipitates, strength-ductility paradox, embrittlement, dislocation interactions

\section{INTRODUCTION}

Nanostructured steels are generically referred as highstrength steels with nanometer-scale structures. According to Bhadeshia [1], the term 'nanostructures' carries a more stringent meaning and is defined as nano-scale features with a large interfacial area to volume ratio $\left(S_{\mathrm{v}}\right)$ over $0.04 \mathrm{~nm}^{-1}$. The conventional nanostructured steels usually have ultra-fine grains and low uniform tensile elongations [2]. Large deformation or severe plastic deformation is often required to obtain such ultra-fine grains, complicating the steel manufacturing process, especially in the production of large parts or cast products [3]. Recently, a new class of fully commercialized bainitic nanostructured steels well suited for a large-scale largepart production was successfully developed by Bhadeshia et al. $[1,4]$. However, these steels require a long aging time and are difficult to be welded due to their high carbon content. In this review, we will focus on the recently developed low-carbon advanced nanostructured steels strengthened with a high number density of ultrafine coherent $\mathrm{Cu}$ and $\mathrm{NiAl}$ precipitates [5-17]. Due to the presence of densely dispersed ultrafine precipitates, these advanced nanostructured steels have a high $S_{\mathrm{v}}$ ratio around $0.03 \mathrm{~nm}^{-1}$, very close to the Bhadeshia's definition. Besides, Liu and co-workers [18] discovered that, through simultaneous $\mathrm{Cu}$ and $\mathrm{Mn}$ alloying additions together with simple thermo-mechanical treatments, it is possible to obtain multi-phase ultrafine $\mathrm{Cu}$ precipitatestrengthened steels with submicrometer-sized ( $\sim 300$ to $500 \mathrm{~nm})$ grains without complicated processing routes

\footnotetext{
${ }^{1}$ Department of Mechanical Engineering, City University of Hong Kong, Hong Kong, China

${ }^{2}$ Department of Mechanical Engineering \& Shenzhen Research Institute, The Hong Kong Polytechnic University, Hong Kong, China

${ }^{3}$ Department of Materials Science and Engineering, City University of Hong Kong, Hong Kong, China

${ }^{4}$ Center for Advanced Structural Materials, Department of Mechanical Engineering, City University of Hong Kong, Hong Kong, China

${ }^{5}$ Hong Kong Institute for Advanced Study, City University of Hong Kong, Hong Kong, China

* Corresponding author (email: chainliu@cityu.edu.hk)
} 
generally required in the conventional ultra-fine grain steels. As depicted in Fig. 1, these nano-precipitatestrengthened advanced nanostructured steels show an excellent strength-ductility balance and outperform the conventional dual phase (DP), transformation induced plasticity (TRIP), and high carbon martensitic (MART) steels [13]. On top of that, these advanced nanostructured steels have superior weldability due to the low level $(<$ $0.15 \mathrm{wt} \%)$ carbon additions $[19,20]$. In spite of their ultrahigh yield strength (YS, $\sim 1$ to $2 \mathrm{GPa}$ ), their tensile reduction area (RA) can reach over $40 \%$, indicating an excellent fabricability. Moreover, they are relatively cheaper (raw material cost) than the traditional highstrength maraging steels containing a high level of expensive elements such as Co and Ti. All these attractive properties allow the advanced low-carbon nanostructured steels to serve in various important structural engineering applications involving transportation, infrastructure, maritime, energy, and defense industries [8,21-24]. These advanced nanostructured steels are normally homogenized at $900-950^{\circ} \mathrm{C}$ and isothermally aged at a relatively lower temperature around $400-550^{\circ} \mathrm{C}$, as depicted in Fig. 2a. In order to produce a complex heterogeneous microstructure consisting of multiple nano-scale phases, multi-step heat treatments presented in Fig. $2 \mathrm{~b}$ are required. Liu and co-workers [18] have demonstrated that a short annealing at $700^{\circ} \mathrm{C}$ can induce a partial recrystallization and the formation of submicrometer-sized $(\sim 300$ to $500 \mathrm{~nm})$ austenite grains that later transform into submicron-martensitic grains during the water quenching of the nanostructured steels containing $\mathrm{Cu}$ and $\mathrm{Mn}$ additions. The subsequent double-step lowtemperature annealing at 640 and $500^{\circ} \mathrm{C}$ will stimulate the formation of relatively stable submicrometer-sized $(\sim 300$ to $500 \mathrm{~nm}$ ) reversed austenite grains along with the precipitation of coherent $\mathrm{Cu}$ precipitates $(\sim 3$ to $4 \mathrm{~nm})$ located at grain boundaries. This complex heterogeneous microstructure results in better dislocation accumulation mechanisms that bring an enhanced strength-ductility

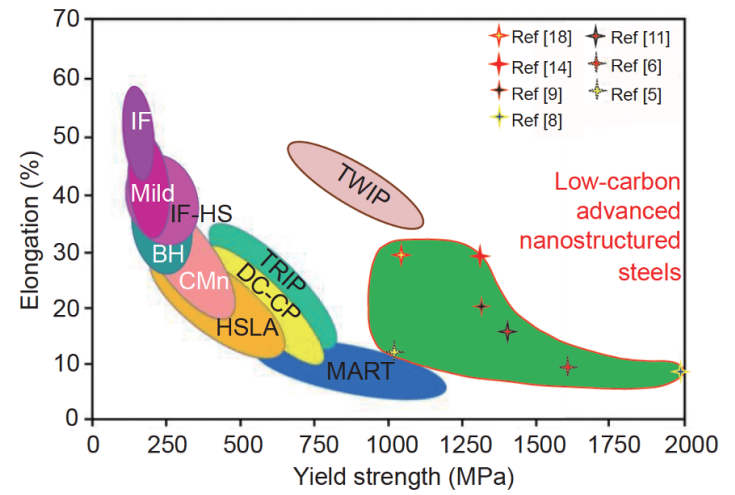

Figure 1 A comparison on the strength-ductility performances of the recently developed low-carbon advanced nanostructured steels with the conventional commercialized steels $[5,6,8,9,11,13,14,18,139]$.

balance and will be further elaborated in the text later. Raising the homogenization temperature to above $900^{\circ} \mathrm{C}$ can help improve strengths due to enhanced supersaturation [9]. However, a care should be taken as performing homogenization at too high temperatures, such as above $1050^{\circ} \mathrm{C}$, which can lead to steel softening due to an excessive grain growth. Homogenization at above $1250^{\circ} \mathrm{C}$ can also encourage the formation of Widmanstaten ferrite and deteriorate the impact toughness [25]. Another feasible processing route of the advanced nanostructured steels involves interphase precipitation during the continuous cooling from the $900^{\circ} \mathrm{C}$ homogenization, as shown in Fig. 2c, particularly useful for ascast products [26]. The process parameters and compositions of some recently developed low-carbon nanoprecipitate-strengthened advanced nanostructured steels are also tabulated in Table 1.

\section{TOWARDS THE GIGAPASCAL GRADE NANO-PRECIPITATE-STRENGTHENED LOW-CARBON DUCTILE ADVANCED NANOSTRUCTURED STEELS}

With the recent rapid growth of the world population and
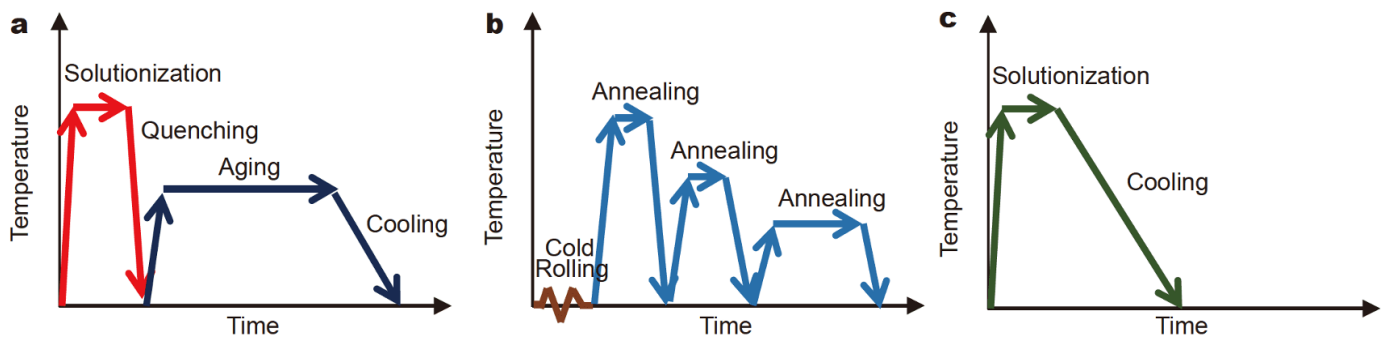

Figure 2 A schematic showing the processing route of the nano-precipitate-strengthened low-carbon advanced nanostructured steels through (a) isothermal aging, (b) multi-step heat treatment, and (c) inter-phase precipitation. 
Table 1 The process parameters and compositions of some recently developed low-carbon nano-precipitate-strengthened nanostructured steels

\begin{tabular}{|c|c|c|c|c|c|c|}
\hline & \multirow{2}{*}{ Composition (wt\%) } & \multicolumn{2}{|c|}{ Solutionization } & \multicolumn{2}{|c|}{ Aging } & \multirow{2}{*}{ Ref. } \\
\hline & & Temperature $\left({ }^{\circ} \mathrm{C}\right)$ & Duration $(\mathrm{h})$ & Temperature $\left({ }^{\circ} \mathrm{C}\right)$ & Duration (h) & \\
\hline 1 & Fe-5Ni-1Al-3Mn & 900 & 0.5 & 550 & 2 & [7] \\
\hline 2 & $\mathrm{Fe}-2.86 \mathrm{Cu}-1.02 \mathrm{Al}-1.48 \mathrm{Mn}-4.23 \mathrm{Ni}$ & 900 & 1 & 500 & 10 & {$[11]$} \\
\hline 3 & Fe-18Ni-3Al-4Mo-0.8Nb-0.08C-0.01B & 950 & 0.25 & 500 & 3 & [8] \\
\hline 4 & $\begin{array}{c}\mathrm{Fe}-0.75 \mathrm{Cu}-2 \mathrm{Cu}-0.75 \mathrm{Mn}-0.3 \mathrm{Al}-2.25 \mathrm{Cr}-1 \mathrm{Mo}- \\
0.25 \mathrm{~V}-0.07 \mathrm{Ti}-0.3 \mathrm{Si}-0.01 \mathrm{~B}-0.08 \mathrm{C}\end{array}$ & 900 & 0.5 & 550 & 2 & [5] \\
\hline 5 & $\begin{array}{c}\text { Fe-2Cu- } 0.045 \mathrm{C}-0.68 \mathrm{Al}-2.83 \mathrm{Ni}-0.5 \mathrm{Mn}- \\
0.065 \mathrm{Nb}-0.01 \mathrm{P}-0.003 \mathrm{P}\end{array}$ & 900 & 1 & 500 & 2 & {$[10]$} \\
\hline 6 & $\mathrm{Fe}-2.5 \mathrm{Cu}-1.5 \mathrm{Mn}-4 \mathrm{Ni}-1 \mathrm{Al}$ & 900 & 1 & 500 & 10 & {$[140]$} \\
\hline 7 & $\begin{array}{c}\text { Fe-3Mn-3Cu- } 4 \mathrm{Ni}-1.5 \mathrm{Al}-0.05 \mathrm{C}-0.07 \mathrm{Nb}- \\
0.53 \mathrm{Si}\end{array}$ & 950 & 1 & 550 & 2 & [9] \\
\hline 8 & $\begin{array}{l}\text { Fe-5Ni-2Al-3Mn- } 1.5 \mathrm{Cu}-1.5 \mathrm{Mo}-1.5 \mathrm{~W}- \\
0.07 \mathrm{Nb}-0.05 \mathrm{C}-0.01 \mathrm{~B}\end{array}$ & 900 & 0.5 & 550 & 2 & [6] \\
\hline 9 & $\begin{array}{c}\text { Fe-9Mn-4Ni-1 Al-2.5Cu-1.5Mo-1.5W-0.1Ti- } \\
0.05 \mathrm{Nb}-0.5 \mathrm{Si}-0.08 \mathrm{C}\end{array}$ & 900 & 1 & 500 & 0.5 & [14] \\
\hline 10 & $\begin{array}{l}\text { Fe- } 8 \mathrm{Mn}-1 \mathrm{Ni}-2 \mathrm{Cu}-3 \mathrm{Cr}-1.1 \mathrm{Si}-0.8 \mathrm{Mo}-0.5 \mathrm{Al}- \\
0.3 \mathrm{Ti}-0.11 \mathrm{C}-0.02 \mathrm{~B}\end{array}$ & - & - & $500-700$ & 0.1 to 2 & [18] \\
\hline
\end{tabular}

the global quest to reduce the carbon dioxide emission, new cheap weldable advanced nanostructured steels with an ultra-high-strength (YS $>1 \mathrm{GPa}$ ), satisfactory toughness (tensile elongation $>10 \%$; impact toughness $>200$ J at $-40^{\circ} \mathrm{C}$ ), and good fabricability (area reduction $>60 \%$ ) are critically needed. The achievement of such ultra-highstrength improvement in the low-carbon advanced nanostructured steels without a loss of ductility through the dense dispersion of ultrafine nano-scale precipitates is of great technological importance. Just by increasing the use of high-strength steels by $35 \%$, the carbon emission can be cut down by at least 70\% [27]. However, the conventional high-strength steels contain a high level of carbon, making these steels difficult to weld. The weldability of a steel is very important in the real-world application. For instance, the welding work can contribute to about $30 \%$ of the total cost in ship building [28].

Recently, Huang's group [29,30] successfully developed an ultra-high-strength steel of YS $\sim 2.2 \mathrm{GPa}$ along with a superb tensile uniform elongation of $\sim 16 \%$ and fracture toughness $\left(K_{\text {JIC }} \sim 102 \mathrm{MPa} \mathrm{m}^{0.5}\right)$. However, the steel has a serious welding issue due to a very high level of carbon $(0.47 \mathrm{wt} \%)$. Moreover, this steel requires a processing step involving an extensive plastic deformation during the manufacturing, thus limiting their use in as-cast products. On the other hand, the nano-precipitate-strengthened high-strength steel (YS $\sim 1.4 \mathrm{GPa}$ and uniform tensile elongation $\sim 7 \%$ ) developed by Raabe et al. [31] contains a very minimal level $(\sim 0.01 \mathrm{wt} \%)$ of carbon. Due to the low level of carbon, the steel has good weldability. Never- theless, the tensile strengths and uniform elongation are only half of that of Huang's ultra-high-strength steel. At any rate, both these two steels contain a high level of $\mathrm{Mn}$ $(\sim 10-12 \mathrm{wt} \%)$. Mn can vaporize easily during steel smelting and is disfavoured by the steel industry.

\section{The roles of alloying additions}

The low-carbon advanced nanostructured steels are composed of a complex chemistry with various alloying additions, as summarized in Table 1. The three elements of $\mathrm{Cu}, \mathrm{Ni}$, and $\mathrm{Al}$ are added primarily to form $\mathrm{Cu}$-rich and $\mathrm{NiAl}$ precipitates due to their reduced solubility limit or the presence of a miscibility gap in the body-centered cubic (BCC) Fe matrix as temperature decreases [5,32]. In order to obtain highly dispersed coherent $\mathrm{Cu}$-rich nanoscale precipitates, $\mathrm{Ni}$ additions are essential to reduce the energy barrier of nucleation by lowering the interfacial energy as well as the elastic misfit strain energy [5]. On the other hand, $\mathrm{Mn}$ additions are required for a dense dispersion of coherent NiAl precipitates [7]. Mo additions were also reported to increase the nucleation density of NiAl precipitates by reducing the lattice misfit at the precipitate-matrix interface, apart from slowing the coarsening kinetics of the precipitates [8]. The additions of $\mathrm{Mn}$ are also beneficial for stabilizing the austenite phase that permits the martensite formation in the subsequent quenching or deformation, which is important for the development of strong yet ductile nanostructured steels [18]. The complex interactions among the alloying additions are further elaborated in the section of 


\section{"NANOSCALE $\mathrm{Cu}$ AND NiAl PRECIPITATIONS IN NANOSTRUCTURED STEELS".}

\section{Cu-rich nano-precipitate strengthening}

$\mathrm{Cu}$-rich precipitation has been used in the high-strength low-alloy (HSLA) steel series since about a decade ago, for replacing the high yield (HY) steel which is difficult to weld. This HSLA steel series contain overaged $\mathrm{Cu}$-rich precipitates with its YS in the range of 550-850 MPa.

Enormous efforts have been put forth by several research groups to maximize the strength of these nanostructured steels hardened by the $\mathrm{Cu}$-rich precipitation. Fine's group [33] from the Northwestern University started off by removing the Mo and Cr from the steel chemistry to reduce the hardenability and thus producing ferritic steels fully strengthened by $\mathrm{Cu}$-rich precipitates $(\mathrm{NuCu} 60$ and $\mathrm{NuCu} 70)$. These steels contain $\mathrm{Cu}, \mathrm{Ni}$, $\mathrm{Mn}$, and $\mathrm{C}$ additions of $1.3-1.4,0.5-0.85,0.5-0.8$, and 0.03-0.06 wt\%, respectively. The steel billets were homogenized at $1093^{\circ} \mathrm{C}$, hot rolled to $12.2-\mathrm{mm}$-thick plates with a finish rolling temperature of $871^{\circ} \mathrm{C}$, and then air cooled to room temperature [34]. With this thermal history, these steels can achieve YS of 400-500 MPa, tensile elongation of $27 \%-36 \%$, and impact toughness of $>136 \mathrm{~J}$ at $-40^{\circ} \mathrm{C}[33,35]$. The low YS of these steels are believed to be attributed to the relatively thick specimens and slow cooling rates that result in growth and coarsening of $\mathrm{Cu}$-rich precipitates $[25,36]$. The steels were used for the construction of a bridge in Lake Villa, Illinois in 2005 [37]. In the steel manufacturing, steel sheets are normally coiled up to facilitate storage and transport process. The coiled steels are then uncoiled for the subsequent treatments before obtaining the final products. Steels with a low YS during the uncoiling stage but with an increased strength for meeting the requirements of a product at the final stage are often desirable. Precipitation strengthening is one of the good approaches. For example, the ferritic $\mathrm{NuCu} 60$ and $\mathrm{NuCu} 70$ steels have a low YS ( 400-500 MPa) in the as-hot-rolled state. These steels can achieve a higher YS ( 700 MPa) easily by a simple $900^{\circ} \mathrm{C}$ water quenching with a subsequent isothermal aging at $525^{\circ} \mathrm{C}$ for $1 \mathrm{~h}[33,35]$.

A few years later, a low-carbon advanced nanostructured steel named $\mathrm{NuCu} 140$ with even a higher YS reaching $965 \mathrm{MPa}$, targeting for the explosion resistant steel application, was developed for United State Navy [35]. It was produced by $900^{\circ} \mathrm{C}$ water quenching and a subsequent heat treatment at $550^{\circ} \mathrm{C}$ for $2 \mathrm{~h}$ to acquire a high number density (order of magnitude approaching $10^{24} \mathrm{~m}^{-3}$ ) of ultrafine $3 \mathrm{~nm}$ coherent $\mathrm{Cu}$-rich precipitates homogeneously dispersed in the ferritic matrix [35]. Different from $\mathrm{NuCu} 60$ and $\mathrm{NuCu} 70, \mathrm{NuCu} 140$ contains minor $\mathrm{Al}$ additions of $0.69 \mathrm{wt} \%$ and a substantially higher $\mathrm{Ni}$ percentage of $2.87 \mathrm{wt} \%$ [35]. $\mathrm{NuCu} 170$, a ferritic advanced nanostructured steel with YS approaching $1200 \mathrm{MPa}$, was also produced by increasing the $\mathrm{Ni}$ and $\mathrm{Cu}$ content to 2.83 and $2.09 \mathrm{wt} \%$, respectively $[10,21,38]$. On the other hand, Jiao et al. [5] discovered the synergistic effects of $\mathrm{Ni}$ additions on the nucleation of $\mathrm{Cu}$-rich precipitates. They successfully developed a lowcarbon ferritic advanced nanostructured steel $(\mathrm{Cu} / \mathrm{Ni}$ steel) that achieved the YS of $1042 \mathrm{MPa}$ while keeping a satisfactory uniform tensile elongation of $10 \%$ (the area reduction over $60 \%$ ) with only a minimal $\mathrm{Ni}$ content. $\mathrm{Ni}$ additions of 0.75 to $2 \mathrm{wt} \%$ of $\mathrm{Cu}$ were sufficient to yield a high number density $\left(7 \times 10^{23} \mathrm{~m}^{-3}\right)$ of ultrafine $(3 \mathrm{~nm})$ coherent BCC $\mathrm{Cu}$ precipitates, as depicted in Fig. 3. This is an important discovery as it implies a significant cost reduction due to only a minimal $\mathrm{Ni}$ addition which is required to induce a significant strength improvement $(437 \mathrm{MPa})$ at a very minimal cost of ductility. The grain size reduction due to the reduced austenite to ferrite transformation temperature as a result of $\mathrm{Ni}$ and $\mathrm{Cu}$ additions also contributes to an additional strengthening and ductility. The reduced grain size allows the activation of more slip systems, leading to a more homogenized slip distribution and therefore an improved ductility [39]. The high area reduction $(\sim 60 \%)$ suggests that Jiao and Liu's

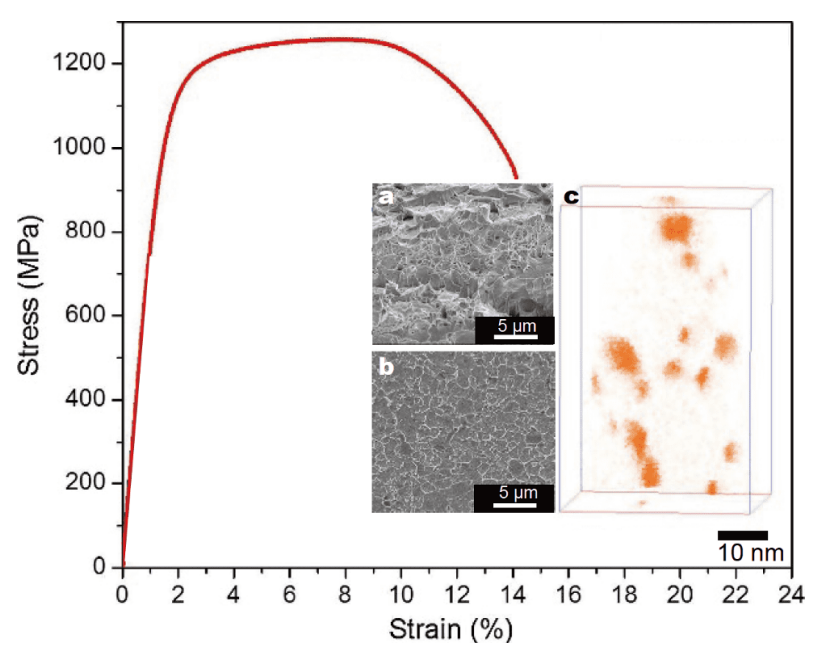

Figure 3 The tensile stress-strain curve of Jiao and Liu's nanostructured steel strengthened with nanoscale coherent $\mathrm{Cu}$ precipitates $(\mathrm{Fe}-0.75 \mathrm{Ni}$ 2Cu-0.75Mn-0.3Al-2.25Cr-1Mo-0.25V-0.07Ti-0.3Si-0.01B-0.08C, wt\%). The snippet view: (a) the dimples indicating ductile fracture; (b) the ferritic grains; (c) the $\mathrm{Cu}$ precipitates through the three-dimensional (3D) reconstruction of atom probe tomography (APT) analyses. Reprinted with permission from Ref. [5]. Copyright 2013, Elsevier. 
$\mathrm{Cu}$-rich nano-precipitate-strengthened advanced nanostructured steel possesses a high workability and is well suited for applications that require a large cold work, such as the anti-roll bars for maintaining the stability of a vehicle during fast cornering [40]. A recent breakthrough in the strength-ductility paradox with a triple ductility enhancement (uniform tensile elongation $\sim 27 \%$ ) at no expense of strengths (YS $1100 \mathrm{MPa}$ and ultimate tensile strength (UTS) $\sim 1300 \mathrm{MPa}$ ) through combined $\mathrm{Cu}$ and $\mathrm{Mn}$ additions with simple low-temperature double-step heat treatments was reported by Liu's group [18]. The additions of Mn have been found to be effective in improving the ductility of these steels. Bhadeshia [41] pointed out that the large ductility of Mn steels does not seem rely solely on the TRIP but most probably due to the resultant complex deformation behavior of different phases. Raabe and co-workers [42] believe that the large ductility is attributed to the austenite grains with different stabilities which contribute to a large deformation regime. Based on the work by Liu's group [18], the combined $\mathrm{Cu}$ and $\mathrm{Mn}$ additions encourage the formation of stable and hard submicrometer-sized ( 300 to $500 \mathrm{~nm})$ reversed austenite grains along with nanoscale coherent $\mathrm{Cu}$ precipitates located at grain boundaries, as demonstrated in Fig. 4e. These relatively hard submicrometer-sized $(\sim 300$ to $500 \mathrm{~nm}$ ) reversed austenite grains, in addition to the dislocations pinning by the coherent $\mathrm{Cu}$ precipitates, contribute to the strength of the steel. Meanwhile, the ductility arises from the synergistic effects of $\mathrm{Cu}$ precipitates in stabilizing the austenite grains that result in a more gradual release of stress through progressive TRIP as well as creating a more heterogeneous strain partitioning [43-47]. The strain partitioning leads to an enhanced dislocation accumulation and work hardening due the formation of stress-strain gradients as a result of the pile-up of geometrical necessary dislocations near the grain boundaries and the generation of long-range back stresses $[48,49]$. The coherent $\mathrm{Cu}$ precipitates at the grain boundaries also strengthen the grain boundaries by promoting a better stress-strain transfer and avoiding the stress-strain localization as a consequence of grainboundary dislocation thickening $[44,46]$. A microstructure with gradient structures [50,51] and a minimized strain contrast $[52,53]$ among the adjacent phases is effective in suppressing the stress-strain localization, resulting in an enhanced strength-ductility synergy.

\section{NiAl nano-precipitate strengthening}

In order to develop advanced nanostructured steels with even a higher strength, researchers $[7,8,54]$ started to

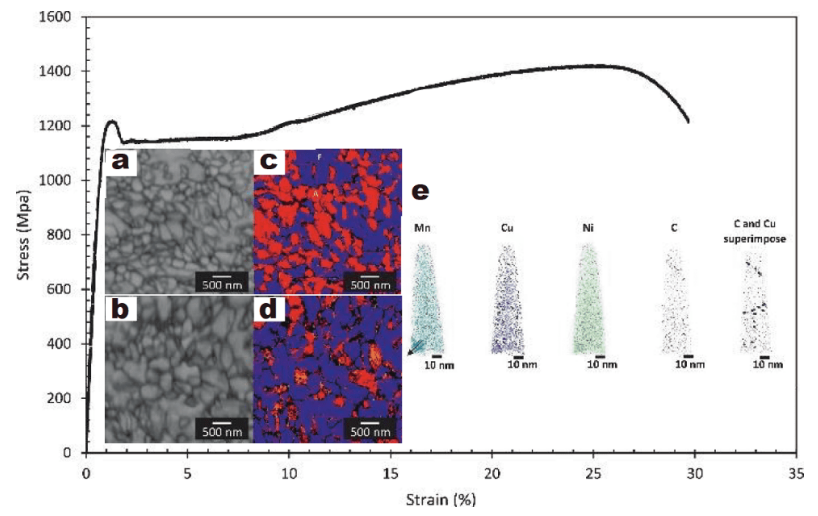

Figure 4 The tensile stress-strain curve of $\mathrm{Cu}$ precipitate-strengthened nanostructured steel containing $8 \mathrm{wt} \%$ of $\mathrm{Mn}$ additions $(\mathrm{Fe}-8 \mathrm{Mn}-1 \mathrm{Ni}-$ 2Cu-3Cr-1.1Si-0.8Mo-0.5Al-0.3Ti-0.11C-0.02B, wt\%). The snippet views: $(a, b)$ the multi-phase submicron-grains before test and after $5 \%$ deformation; (c, d) the phase map before test and after $5 \%$ deformation, indicating TRIP effect during deformation; (e) the nanoscale coherent $\mathrm{Cu}$ precipitates sitting along the grain boundaries through the $3 \mathrm{D}$ reconstruction of APT analyses. F: ferrite; A: austenite; Red: face-centered cubic (FCC) phase; Blue: BCC phase; Orange: hexagonal close-packed phase. Reprinted with permission from Ref. [18]. Copyright 2020, Elsevier.

borrow the idea from the maraging steels and derive strength from intermetallic compounds [55-60]. NiAl is an intermetallic compound and incorporating it in steels can lead to serious brittleness [54,61-63]. Jiao et al. [7] successfully turned brittleness into ductility and developed an advanced nanostructured steel alloy (Fe-5Ni$1 \mathrm{Al}-3 \mathrm{Mn}$, wt\%) strengthened by a high number density of ultrafine coherent NiAl precipitates. This advanced nanostructured steel alloy is carbon free. With a simple heat treatment at $550^{\circ} \mathrm{C}$ for $2 \mathrm{~h}$ preceded by a water quenching from the $900^{\circ} \mathrm{C} 30-\mathrm{min}$ homogenization, it can achieve a strength $(\mathrm{YS}=1225 \mathrm{MPa}$ ) comparable to the $\mathrm{PH} 13-8$ type maraging steel $(\mathrm{YS}=1200 \mathrm{MPa}$ ) with almost no loss of tensile ductility, as depicted in Fig. 5. The tensile ductility and RA can be maintained at $14 \%$ and over $50 \%$, respectively. For the steel to be cost competitive, Jiao et al. [7] kept the Ni content at only $5 \mathrm{wt} \%$, lower than that of the PH 13-8 maraging steel $(\sim 8 \mathrm{wt} \%$ of $\mathrm{Ni})$. They discovered that $\mathrm{Mn}$ additions are very important as $\mathrm{Mn}$ is cheap and, more importantly, the number density of NiAl precipitates is increased by at least 50 times, from the order of $\sim 10^{22}$ to $\sim 10^{24} \mathrm{~m}^{-3}$ and at the same time reducing the size of the precipitates to $2.8 \mathrm{~nm}$ in diameter, resulting in a three-fold strength increment by $540 \mathrm{MPa}$. The $\mathrm{NiAl}$ precipitates in Jiao and Liu's Fe-5Ni-1Al-3Mn nanostructured steel [7] and the $\mathrm{Cu}$-rich precipitates in Jiao and Liu's $\mathrm{Cu} / \mathrm{Ni}$ nanostructured steel [5] have the similar 


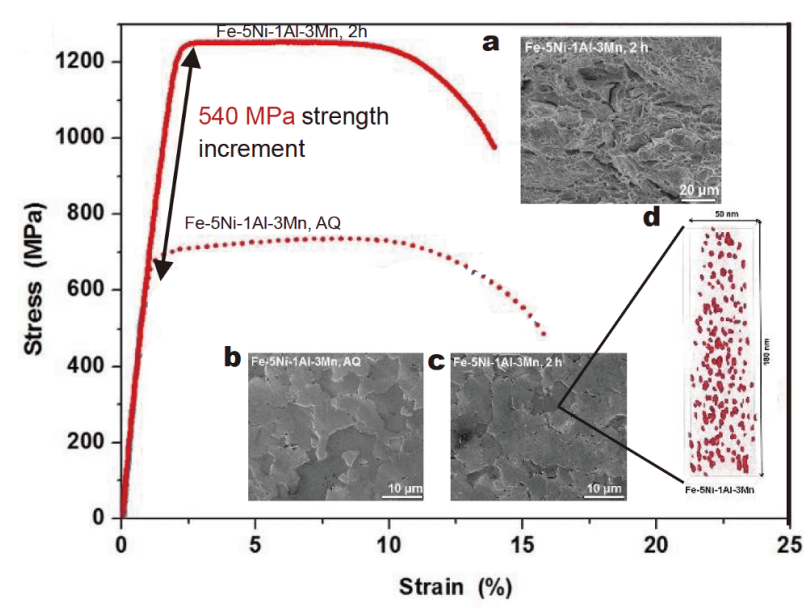

Figure 5 The tensile stress-strain curve of Jiao and Liu's Fe-5Ni-1Al$3 \mathrm{Mn}$ advanced nanostructured steel. A huge strength increment of $540 \mathrm{MPa}$ was achieved without a significant loss of ductility due to the ultrafine dispersion of high number density coherent NiAl nano-precipitates after aging at $550^{\circ} \mathrm{C}$ for $2 \mathrm{~h}$. The snippet views: (a) the ductile fracture; (b, c) the ferritic grains before and after the $550^{\circ} \mathrm{C} / 2 \mathrm{~h}$ aging; (d) the NiAl precipitates through the $3 \mathrm{D}$ reconstruction of APT analyses. AQ: as quenched. Reprinted with permission from Ref. [7]. Copyright 2015, Elsevier.

size and number density, yet the strength increment due to the NiAl precipitation $(540 \mathrm{MPa})$ is higher than that of the $\mathrm{Cu}$ precipitates $(437 \mathrm{MPa})$. This suggests that nanoscale $\mathrm{NiAl}$ precipitates are harder and have a higher intrinsic strength. The beneficial effects of Mn additions are attributed to the substitution of Al sublattice by the $\mathrm{Mn}$ atoms, reducing the critical energy formation of $\mathrm{NiAl}$ precipitates.

Jiang et al. [8] also reported an unusual behavior of an advanced nanostructured steel strengthened by a dispersion of a high number density (over $3.7 \times 10^{24} \mathrm{~m}^{-3}$ ) of ultrafine $(\sim 2.7 \mathrm{~nm}$ in diameter $)$ coherent $\mathrm{NiAl}$ precipitates with minimal lattice misfit $(\sim 0.03 \%)$ in a martensitic matrix. Jiang and Lu's steel has an elemental composition very similar to the grade 350 or $18 \mathrm{Ni}$ maraging steel but with the replacement of expensive Co $(\sim 11 \mathrm{wt} \%)$ and $\mathrm{Ti}(\sim 1.5 \mathrm{wt} \%)$ with $\mathrm{Al}(3 \mathrm{wt} \%)$ which is cheaper. With this new chemistry, their new steel does not rely on the strengthening from the $\mathrm{Ni}_{3} \mathrm{Ti}$ and $\mathrm{Ni}_{3} \mathrm{Mo}$ precipitates as in the traditional 350 maraging steel. This saves more $\mathrm{Ni}$ atoms for the steel matrix, creating a higher supersaturation or driving force for nucleation and thus finer and higher number density $\mathrm{NiAl}$ precipitates. After the $900^{\circ} \mathrm{C}$ solutionization for $15 \mathrm{~min}$ followed with a $500^{\circ} \mathrm{C}$ aging for $3 \mathrm{~h}$, this advanced nanostructured steel can achieve a tensile YS over $2 \mathrm{GPa}$. The strength-ductility paradox is a common scenario for almost all mate-

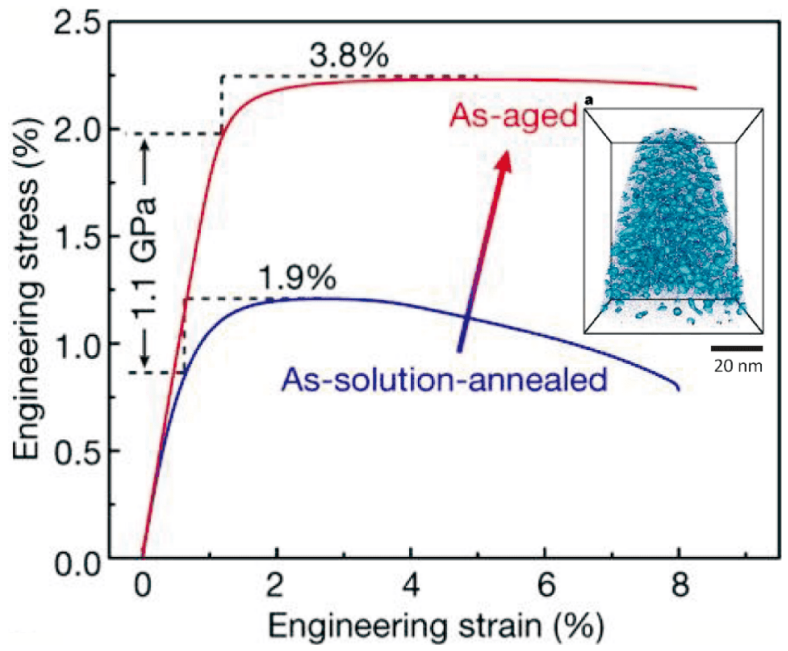

Figure 6 The tensile stress-strain curve of Jiang and Lu's advanced nanostructured steel (Fe-18Ni-3Al-4Mo-0.8Nb-0.08C-0.01B) strengthened with ultrafine dispersion of coherent $\mathrm{NiAl}$ nano-precipitates, as demonstrated in the snippet view. Both strength and uniform elongation were improved after aging, breaking the strength-ductility trade-off. Reprinted with permission from Ref. [8]. Copyright 2017, Springer Nature.

rials. Nevertheless, as described in Fig. 6, Jiang and Lu's steel behaves very unusually in the sense that the tensile uniform elongation increases from $1.9 \%$ to $3.8 \%$ as the YS increases from $900 \mathrm{MPa}$ to $2 \mathrm{GPa}$ upon the $500^{\circ} \mathrm{C}$ treatment. In other words, the dispersion of a high number density of ultrafine coherent precipitates in steels can serve as effective barriers for dislocation motion and at the same time delaying the initiation of necking instability, breaking the common notion of strength-ductility paradox. This is an important discovery as real engineering applications require both the strength and ductility.

On the other hand, Liaw's group focused on the development of low-cost advanced nanostructured steels for steam turbine applications. The conventional NiAl precipitate-strengthened maraging steels such as $\mathrm{PH} 13-8$ have intermediate service temperatures below $600^{\circ} \mathrm{C}$, due to the low volume fraction $(\sim 3 \%)$ of $\mathrm{NiAl}$ precipitates $[32,55]$ and low reversed austenite temperature $\left(<600^{\circ} \mathrm{C}\right)$ [55,64-68]. Liaw's group [62,69] developed a nanostructured ferritic steel (FBB-8: Fe-6.5Al-10Cr-10Ni3.4Mo-0.25Zr-0.005B, wt\%) with a high-volume fraction $(\sim 16 \%)$ of $\mathrm{NiAl}$ precipitates. A high-volume fraction of $\mathrm{NiAl}$ precipitates is crucial for enhanced creep resistance but often results in poor room temperature ductility (bending ductility <2\%) $[63,70]$. The $\mathrm{NiAl}$ precipitates in the FBB- 8 steel are of duplex-type: large $(\sim 100 \mathrm{~nm}$ in 
diameter) primary and ultrafine $(\sim 3 \mathrm{~nm}$ in diameter) secondary nanoscale $\mathrm{NiAl}$ precipitates. These precipitates are coherent with the ferritic matrix with a near-zero lattice misfit $(0.06 \%$ for the primary precipitates), for a low driving force for coarsening [54,62,71]. Compared with the Jiao and Liu's [7] and Jiang and Lu's [8] nanostructured steels, Liaw's FBB- 8 steel has the highest volume fraction of $\mathrm{NiAl}$ precipitates. The precipitate-distribution parameters including the volume fraction, size and number density of the NiAl precipitates of these steels are listed in Table 2. Moreover, Liaw's group fixed the $\mathrm{Al}: \mathrm{Ni}$ ratio of the $\mathrm{FBB}-8$ steel at 0.65 , the highest among Jiao and Liu's (Al:Ni = 0.2 [7]), Jiang and Lu's (Al: $\mathrm{Ni}=0.17$ [8]) and $\mathrm{PH} 13-8(\mathrm{Al}: \mathrm{Ni}=0.09$ [55]) steels. A low $\mathrm{Al}: \mathrm{Ni}$ ratio reduces the austenite reverse temperature, leading to a significant strength reduction at the elevated temperatures and thus restricting the steels to only serve in the intermediate temperature environment with operating temperatures below $600^{\circ} \mathrm{C}[55,64-68]$. In spite of the increased $\mathrm{NiAl}$ volume fraction and austenite reversed temperature, the creep resistance of the FBB- 8 steel is still not sufficient for the industrial steam turbine applications above $700^{\circ} \mathrm{C}$ [69], most probably due to the dissolution of the ultrafine secondary $\mathrm{NiAl}$ precipitates at elevated temperatures [62]. In addition, the lack of a load transfer from the steel matrix to the primary $\mathrm{NiAl}$ precipitates attributed from the diffusional flow along the NiAl/matrix can also result in the poor creep resistance [69]. Song et al. [69] improved the creep resistance of the steel by adding $2 \mathrm{wt} \%$ of Ti to create hierarchical structured B2$\mathrm{NiAl} / \mathrm{L}_{2}-\mathrm{Ni}_{2} \mathrm{TiAl}$ precipitates, as shown in Fig. 7. These hierarchical structured precipitates have a strong coherent misfit strain along the matrix/precipitate interface, and they are effective obstacles against the dislocation climb-bypassing or shearing. The modified steel has a creep resistance comparable to the Haynes $282 \mathrm{Ni}$-based superalloys and is well suited for applications up to $760^{\circ} \mathrm{C}$ for ultra-supercritical steam turbines.

\section{Co-nano precipitate strengthening}

Though NiAl precipitates are more effective strengtheners than the $\mathrm{Cu}$ precipitates, in many applications where cost is concerned, deriving strength solely from the expensive $\mathrm{NiAl}$ precipitates might not be favorable. Many researchers $[6,9,11]$ showed their interest in the steels containing multiple components such as $\mathrm{Cu}, \mathrm{Ni}, \mathrm{Al}, \mathrm{Mn}$. Zhang et al. [11] investigated the effects of $\mathrm{Ni}$ on a ferritic multicomponent alloy system (Fe-1.2Al-1.5Mn-2.87Cu,

Table 2 The precipitate-distribution parameters of NiAl precipitate-strengthened nanostructured steels

\begin{tabular}{|c|c|c|c|c|c|c|c|}
\hline \multirow[b]{2}{*}{ Samples (wt\%) } & \multicolumn{3}{|c|}{ Primary precipitates } & \multicolumn{3}{|c|}{ Secondary precipitates } & \multirow[b]{2}{*}{ Ref. } \\
\hline & $\begin{array}{c}\text { Volume } \\
\text { fraction (\%) }\end{array}$ & Radius (nm) & $\begin{array}{c}\text { Number } \\
\text { density }\left(\mathrm{m}^{-3}\right)\end{array}$ & $\begin{array}{c}\text { Volume } \\
\text { fraction }(\%)\end{array}$ & Radius (nm) & $\begin{array}{c}\text { Number } \\
\text { density }\left(\mathrm{m}^{-3}\right)\end{array}$ & \\
\hline $\begin{aligned} \text { Liaw's FBB- } 8 & (\mathrm{Fe}-6.5 \mathrm{Al}-10 \mathrm{Ni}-10 \mathrm{Cr}-3.4 \mathrm{Mo}- \\
& 0.25 \mathrm{Zr}-0.005 \mathrm{~B})\end{aligned}$ & 15.5 & 54 & $2.43 \times 10^{20}$ & 3.5 & 1.5 & $1.06 \times 10^{24}$ & {$[54]$} \\
\hline $\begin{array}{c}\text { Jiang and Lu's low misfit steel } \\
(\mathrm{Fe}-18 \mathrm{Ni}-3 \mathrm{Al}-4 \mathrm{Mo}-0.8 \mathrm{Nb}-0.08 \mathrm{C}-0.01 \mathrm{~B})\end{array}$ & 3.8 & 1.35 & $3.7 \times 10^{24}$ & - & - & - & {$[8]$} \\
\hline Jiao and Liu's Fe-5Ni-1Al-3Mn steel & 0.95 & 1.38 & $8.6 \times 10^{23}$ & - & - & - & {$[7]$} \\
\hline
\end{tabular}
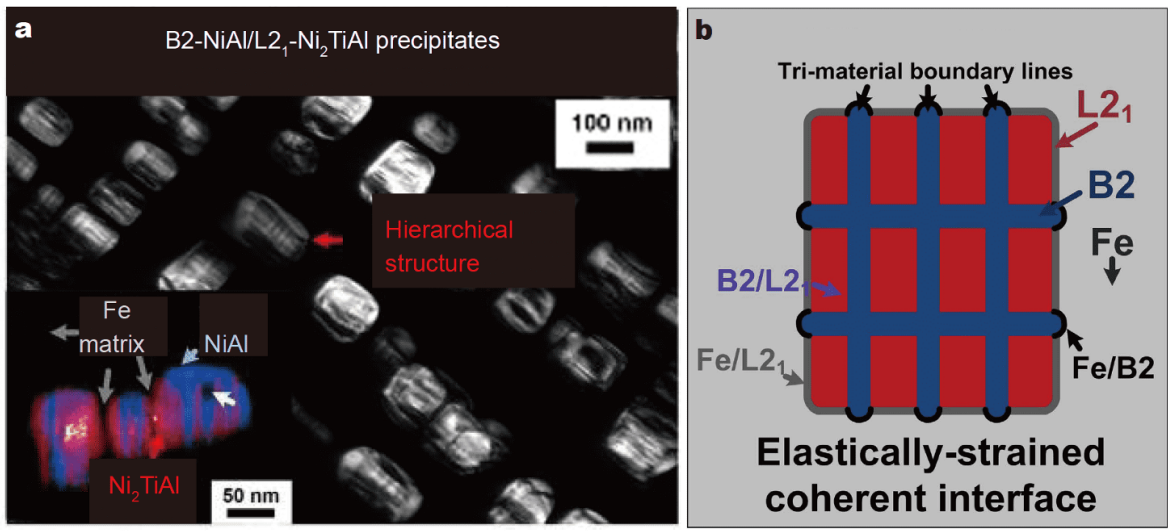

Figure 7 (a) Dark field transmission electron microscopy image and (b) schematic diagram showing the hierarchical $\mathrm{B} 2-\mathrm{NiAl} / \mathrm{L} 2_{1}-\mathrm{Ni}{ }_{2} \mathrm{TiAl}$ precipitates in Song and Liaw's nanostructured steel. Reprinted with permission from Ref. [69]. Copyright 2015, Springer Nature. 
wt\%) and developed a nanostructured steel strengthened with a high number density $\left(3.6 \times 10^{24} \mathrm{~m}^{-3}\right)$ of ultrafine (diameter $\sim 3 \mathrm{~nm}$ ) NiAl and $\mathrm{Cu}$ co-precipitates. The authors discovered that the additions of $4 \mathrm{wt} \% \mathrm{Ni}$ to the steel were able to increase the YS from about $700 \mathrm{MPa}$ in the solution state to approximately $1.4 \mathrm{GPa}$ upon aging, a significant strength increment of nearly $700 \mathrm{MPa}$ with no significant loss of ductility. The total tensile elongation could be still maintained at $\sim 16 \%$. Later, $\mathrm{Xu}$ et al. [14] demonstrated that the total elongation can be further improved by nearly twice, to approximately $30 \%$, after the additions of $9 \mathrm{wt} \%$ of Mn. The YS was slightly reduced to 1.3 GPa while the UTS was maintained at about $1.4 \mathrm{GPa}$. The authors attributed the improved tensile ductility to the cooperative deformation of the soft austenite grains and the adjacent hard tempered martensite grains strengthened mainly by the high number density $(\sim 1 \times$ $\left.10^{24} \mathrm{~m}^{-3}\right)$ of ultrafine $(\sim 3.5 \mathrm{~nm}) \mathrm{Cu}$ and NiAl precipitates. The cooperative deformation triggers the activation of multiple slip systems and suppresses the strain localization as a result of the dynamic stress-strain partitioning and TRIP effect.

Kapoor et al. [9] further increased the strengths of the co-precipitate-strengthened ferritic steel $(\mathrm{Fe}-3 \mathrm{Cu}-4 \mathrm{Ni}-$ $1.5 \mathrm{Al}-3 \mathrm{Mn}-0.07 \mathrm{Nb}-0.53 \mathrm{Si}-0.05 \mathrm{C}$, wt $\%)$ to $1.6 \mathrm{GPa}$ with about $4 \%$ of total tensile elongation by increasing the total concentration of the principal elements $(\mathrm{Mn}+\mathrm{Ni}+\mathrm{Cu}+\mathrm{Al})$ to $11.5 \mathrm{wt} \%$. Increasing the concentration of principal elements can result in two competing consequences. First, the driving force and the volume fraction of the $\mathrm{Cu}$ and $\mathrm{NiAl}$ precipitates will increase, leading to enhanced strength. Secondly, the principal elements $\mathrm{Mn}, \mathrm{Ni}$, and $\mathrm{Cu}$ are austenite stabilizers. The increase of these element concentrations will also increase the concentration of austenite stabilizers. As the principal element concentration goes beyond $11.5 \mathrm{wt} \%$, austenite will easily form during aging; as a result, the steel becomes soft and its YS decreases.

Through computation-aided alloy design strategy, Jiao et al. [6] successfully developed a $\mathrm{Cu}$-rich and $\mathrm{NiAl}$ coprecipitate-strengthened advanced nanostructured steel (Fe-1.5Cu-5Ni-2Al-3Mn-1.5Mo-1.5W-0.07Nb-0.01B$0.05 \mathrm{C}$, wt $\%$ ) containing a low-carbon content with a UTS close to $2 \mathrm{GPa}$ while keeping the total tensile elongation at $\sim 10 \%$. By optimizing the alloying content, the tensile strength (YS $\sim 1.7 \mathrm{GPa}$, UTS $\sim 1.9 \mathrm{GPa}$ ) of this advanced nanostructured steel is only a few hundred MPa below Jiang and Lu's steel [8] (YS $\sim 2 \mathrm{GPa}$, UTS $\sim 2.2 \mathrm{GPa}$ ), yet the cost is relatively cheaper. According to the market price [72,73], Ni is about 45 times more expensive than
Fe. This new steel keeps the expensive $\mathrm{Ni}$ content at a very minimal level of only $5 \mathrm{wt} \%$, compared with the $18 \mathrm{wt} \%$ of Ni content in the Jiang and Lu's steel, lowering the steel material cost by almost $64 \%$. Moreover, it is very interesting to note that even though both the Jiao and Liu's and Kapoor and Isheim's co-precipitate-strengthened steels have the same principal element $(\mathrm{Mn}+\mathrm{Ni}+\mathrm{Cu}$ $+\mathrm{Al}$ ) concentration or supersaturation for nucleation, Jiao and Liu's steel can reach even higher strengths (YS $\sim 1.7 \mathrm{GPa}$, UTS $\sim 1.9 \mathrm{GPa}$ ). Both the steels were peak aged at $550^{\circ} \mathrm{C}$ for $2 \mathrm{~h}$. The principal element concentration of Jiao and Liu's steel was optimized so that the austenite volume fraction maintained below $15 \%$ with no formation of delta-ferrite was permitted. Different from the Kapoor and Isheim's steel, the $\mathrm{Ni}: \mathrm{Cu}$ and $\mathrm{Al}: \mathrm{Cu}$ ratios are relatively higher. The high strengths and improved tensile ductility in Jiao and Liu's steel might be due to the finer and higher number density of $\mathrm{NiAl}$ and $\mathrm{Cu}$ co-precipitates. The $\mathrm{Cu}$ and $\mathrm{NiAl}$ precipitates in Jiao and Liu's steel are around $3 \mathrm{~nm}$ in diameter, twice finer than that of Kapoor and Isheim's steel. Meanwhile, the number density of $\mathrm{Cu}$ and NiAl precipitates in Jiao and Liu's steel are $5 \times 10^{23}$ and $3 \times 10^{24} \mathrm{~m}^{-3}$, respectively, an order of magnitude higher than that of the Kapoor and Isheim's steel. In addition, the presence of nano-scale carbides and reduced grain size can also contribute to a supplementary strengthening effect.

\section{THE IMPACT TOUGHNESS OF THE NANO-PRECIPITATE-STRENGTHENED LOW-CARBON ADVANCED NANOSTRUCTURED STEELS}

Impact toughness is a very important design criterion in many structural applications especially for those involving a low service temperature. It is defined by the minimum energy required for the initiation and propagation of cracks [74]. Ferritic and martensitic steels are susceptible to low-temperature brittleness or embrittlement due to their intrinsic temperature-strength dependency. As the temperature reduces, the YS increases $[75,76]$. Once the temperature drops to below the ductile to brittle transition temperature (DBTT), brittle failure occurs. The sinking of titanic ship is one of the catastrophic metallurgical failures due to the low temperature embrittlement. According to the Yoffee diagram [77], brittle failure occurs once the YS of a steel exceeds its fracture strength. The diagram also suggests that intergranular fracture is the dominant brittle fracture mode when the intergranular fracture strength is lower than the transgranular fracture strength; otherwise, transgranular 
cleavage will be the main brittle failure mode. In the conventional martensitic steels, brittle failures involving both cleavage and intergranular fractures can occur after tempering at temperatures around $200-400^{\circ} \mathrm{C}$ (also called as the irreversible $350^{\circ} \mathrm{C}$ temper martensite embrittlement) due to the precipitation of brittle carbides along the inter-lath and grain boundaries [75,78]. The reversible intergranular $300-600^{\circ} \mathrm{C}$ temper embrittlement is another type of brittle failure commonly found in the ferritic/ martensitic steels due to the segregation of impurities along the prior austenite grain boundaries [79].

The $\mathrm{Cu}$-rich precipitate-strengthened ferritic steels developed by the Fine's group, such as the $\mathrm{NuCu} 60$ and 70 steels, have a superior impact toughness over $136 \mathrm{~J}$ even at a cryogenic temperature of $-40^{\circ} \mathrm{C}[33,35]$. However, the impact toughness reduces to $74 \mathrm{~J}\left(\mathrm{at}-40^{\circ} \mathrm{C}\right)$ as the YS increases to $956 \mathrm{MPa}$ in the $\mathrm{NuCu} 140$ [35]. A similar strength-impact toughness paradox can also be observed in the $\mathrm{Cu}$ precipitate-strengthened HSLA-100 steel, as demonstrated in Fig. 8. The steel achieved its peak strengths after aging at temperatures around $300-600^{\circ} \mathrm{C}$ but at the expense of impact toughness [80]. The impact toughness restored with increasing aging temperature, but it came with reduced strengths. The reduced impact toughness after aging at $300-600^{\circ} \mathrm{C}$ was ascribed to the improved matrix strength as a result of the profuse $\mathrm{Cu}-$ rich precipitation. The steel regained its toughness with higher aging temperatures due to the coarsening of the $\mathrm{Cu}$-rich precipitates. Similar strength-impact toughness trade-off was also reported in the ferritic/martensitic steels containing $\mathrm{Cu}$-rich precipitates developed by Liu

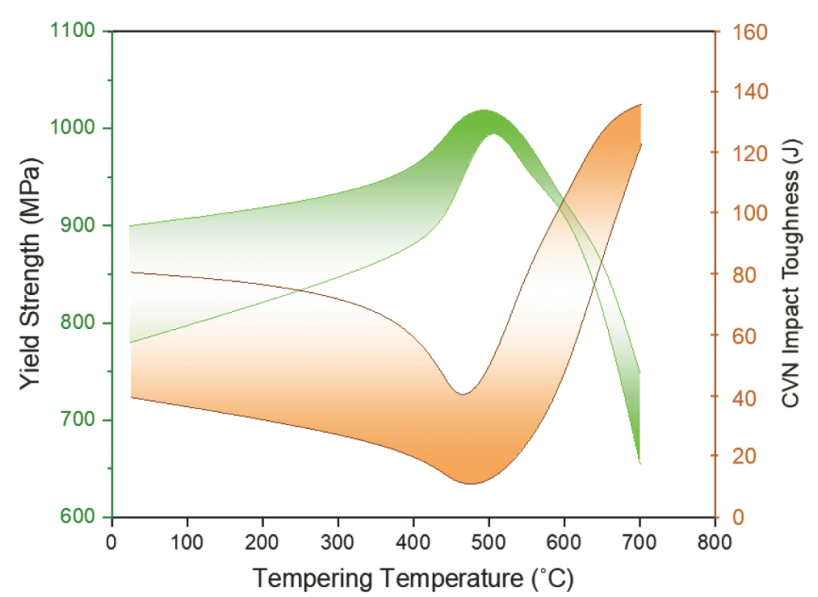

Figure 8 The strength-impact toughness paradox of the HSLA-100 steel. The steel achieves its peak strength after aging at $500^{\circ} \mathrm{C}$ but at the minimum toughness. The impact toughness restores with aging above $600^{\circ} \mathrm{C}$ but at the expense of strength [80]. et al. [81] from Gu's group. These authors found that the strength improvement due to the $\mathrm{Cu}$-rich precipitation during the $500^{\circ} \mathrm{C}$ tempering could lead to a reduced impact toughness. Meanwhile, tempering at temperatures above $600^{\circ} \mathrm{C}$ resulted in improved impact toughness but at the expense of strengths due to the formation of reversed austenite.

As discussed in the earlier sections, the low-carbon $\mathrm{Cu}$ rich nano-precipitate-strengthened advanced nanostructured steels developed by Jiao et al. [5] acquire their strengths obtained from high-number-density ultrafine coherent $\mathrm{Cu}$ precipitates. The nanostructured steels require aging at $550^{\circ} \mathrm{C}$ to obtain the critical precipitate size for the peak strengthening. Nevertheless, this aging temperature falls within the $300-600^{\circ} \mathrm{C}$ embrittlement regime and can result in a low impact toughness as in the HSLA-100 steel. Kong et al. [82] strived to solve this strength-impact toughness paradox. They decreased the $\mathrm{Cu}$ content from the previously $2 \mathrm{wt} \%$ in Jiao and Liu's work to only $1.3 \mathrm{wt} \%$ for reducing the embrittlement and a further cost reduction. The authors reported a successful realization of GPa-grade nanostructured steels (YS and UTS over $1000 \mathrm{MPa}$, tensile ductility more than 10\%) through a simple and short 10 -min heat treatment at $640^{\circ} \mathrm{C}$, avoiding the $300-600^{\circ} \mathrm{C}$ embrittlement regime after the $900^{\circ} \mathrm{C}$ solution treatment. They discovered that the realization of GPa-grade nanostructured steels even after annealing at $640^{\circ} \mathrm{C}$ is due to the multiple strengthening mechanisms. The additions of $\mathrm{Cu}, \mathrm{Ni}$, and $\mathrm{C}$ can stabilize the FCC phase at high temperatures (e.g., $\sim 900^{\circ} \mathrm{C}$ ) and give multiple complex strengthening mechanisms at lower temperatures $\left(<700^{\circ} \mathrm{C}\right)$, depending on the cooling rate and heat treatment conditions. The strengthening mixtures of the nanostructured steels with different heat treatment schedules are presented in Fig. 9.

Moreover, their impact results also suggest that the embrittlement of the nanostructured steels could be attributed to the segregation of impurities along the prior austenite grain boundaries. As the temperature passed through the embrittlement regime during slow cooling or aging, the impurities segregated into the prior austenite grain boundaries, weakening the prior austenite grain boundaries, and thus resulted in a very low impact toughness $\left(<50 \mathrm{~J}\right.$ at $\left.-20^{\circ} \mathrm{C}\right)$ accompanied with the intergranular fracture, as shown in Fig. 10. The nanostructured steels regained their impact toughness $(\sim 200 \mathrm{~J}$ even at $-40^{\circ} \mathrm{C}$ ) after water quenching from the $900^{\circ} \mathrm{C}$ solution treatment followed by aging at temperatures above the embrittlement regime $\left(>600^{\circ} \mathrm{C}\right)$ with a subsequent fast quenching. The fast quenching is the key to 


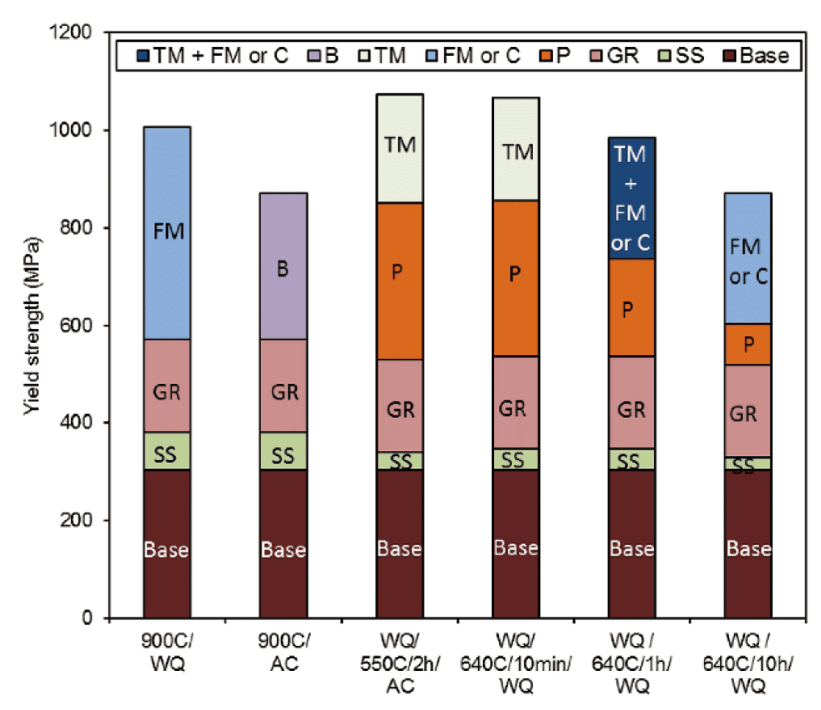

Figure 9 The strengthening mix indicating multiple strengthening mechanisms of the advanced nanostructured steel containing $\mathrm{Cu}$ and $\mathrm{Ni}$ additions. The advanced steel is insensitive to heat treatment and can achieve YS above $1000 \mathrm{MPa}$. FM: fresh martensite; B: bainite; TM: tempered martensite; P: Cu precipitation; C: carbides; GR: grain refinement; SS: solid solution; AC: air cool; WQ: water quench. Reprinted with permission from Ref. [82]. Copyright 2019, Elsevier.

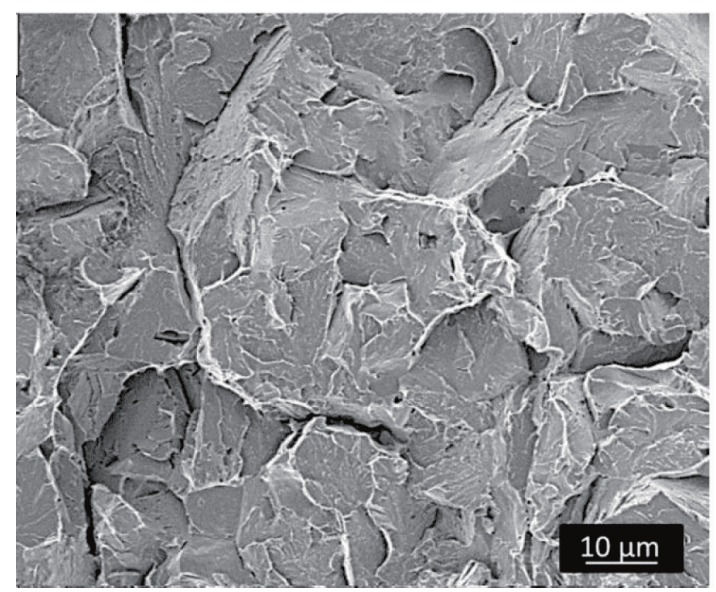

Figure 10 The fractured surface of nanostructured steel containing $\mathrm{Cu}$ and $\mathrm{Ni}$ additions after aging at $600^{\circ} \mathrm{C}$ followed by air cooling, indicating mixed intergranular-cleavage brittle fracture. Reprinted with permission from Ref. [82]. Copyright 2019, Elsevier.

the improved impact toughness of the steels. The impurities boiled off from the prior austenite grain boundaries during the high temperature $\left(>600^{\circ} \mathrm{C}\right)$ aging. The subsequent rapid cooling (such as water quenching) froze the impurities from segregating back to the prior austenite grain boundaries, and hence improved the impact toughness. By optimizing the heat treatment condition, the authors believed the nanostructured steels can obtain their strengths over $1 \mathrm{GPa}$ with a good tensile ductility over $10 \%$ and superior low temperature $\left(-40^{\circ} \mathrm{C}\right)$ impact toughness over $200 \mathrm{~J}$. These properties allow the nanostructured steels to possess strengths and impact toughness more superior than the X80 steel (YS $\sim 550 \mathrm{MPa}$, UTS $\sim 750 \mathrm{MPa}$, impact toughness $\sim 200 \mathrm{~J}$ at $-40^{\circ} \mathrm{C}$ [83]) used in the recent West-East gas pipelines spanning over $5000 \mathrm{~km}$ across China. As indicated in Fig. 10, the nanostructured steels failed through a mixed brittle intergranular-cleavage mechanism. There might be other factors, apart from the impurities segregating along the prior austenite grain boundaries during slow cooling, possibly contributing to the low impact toughness of the nanostructured steels [84].

\section{NANOSCALE Cu AND NiAl PRECIPITATIONS IN NANOSTRUCTURED STEELS}

The nano-precipitates of the advanced nanostructured steels are metastable and maintain a very high coherency with the BCC steel matrix [7]. For instance, the $\mathrm{Cu}$-rich nano-precipitates are ultrafine $(<4 \mathrm{~nm}$ in diameter) and have the BCC structure during the initial stage of nucleation $[5,10,85]$. As the aging proceeds, they grow larger $(>4 \mathrm{~nm})$ and transform martensitically $[86,87]$ into the semi-coherent $9 \mathrm{R}$ structure before turning into the incoherent FCC structure $(>37 \mathrm{~nm})[85,88,89]$. Deformation-induced BCC to $9 \mathrm{R}$ martensitic transformation was also reported [90,91]. Meanwhile, the NiAl nanoprecipitates have the B2 structure [7] and they keep the same structure even after growing into a size as large as $200 \mathrm{~nm}$ in diameter [63]. These $\mathrm{Cu}$-rich and NiAl nanoprecipitates have a spherical morphology in the initial stage of aging. With a prolonged aging, they start to lose their coherency and grow longitudinally, revealing a rodlike $[9,10]$ or cuboidal shape $[13,92]$.

The origin of the $\mathrm{Cu}$-rich nano-precipitation lies behind the limited solubility (only $\sim 0.15 \mathrm{wt} \%$ at $550^{\circ} \mathrm{C}$ ) of $\mathrm{Cu}$ solutes in the BCC Fe solid solution $[93,94]$ and the positive enthalpy of mixing between the $\mathrm{Fe}$ and $\mathrm{Cu}$ atoms [95]. Once cooled down from the homogenization temperature, a solid solution supersaturated with $\mathrm{Cu}$ solutes is created and this drives the nucleation of $\mathrm{Cu}$-rich precipitates. Kolli and Seidman [10] performed a comprehensive study on the composition evolution of the $\mathrm{Cu}$ rich nano-precipitates. At the beginning of the aging process, the core of the ultrafine BCC metastable $\mathrm{Cu}$-rich nano-precipitates contains a significant level of $\mathrm{Fe}(\sim 30$ to 40 at $\%), \mathrm{Ni}(\sim 8$ at $\%), \mathrm{Al}(\sim 6$ at $\%)$, and $\mathrm{Mn}(\sim 1.5$ at $\%)$. The authors suggested that these elements are important 
in stabilizing the metastable BCC Cu-rich nanoprecipitates. Similar observations were also reported by Kapoor et al. [9] and Jiao et al. [94]. Isheim's work [96] on nanostructured steels containing a very low level of $\mathrm{Ni}$ $(0.82 \mathrm{wt} \%)$ and $\mathrm{Al}(0.03 \mathrm{wt} \%)$ also reported strong $\mathrm{Fe}$ (33 at\%) and $\mathrm{Al}(0.5$ at\%) enrichments in the BCC Curich core. Nevertheless, there were also cases where pure BCC $\mathrm{Cu}$ core without the enrichment of alloying elements reported in [5,97-99]. Zhu et al. [100] performed a phase field modelling on the $\mathrm{Cu}$ precipitation in the $\mathrm{Fe}$ $\mathrm{Cu}$ alloy system. Their work suggested that the composition of the $\mathrm{Cu}$ core at the early stages of precipitation depends on the alloy composition and the aging temperature.

As the $\mathrm{Cu}$-rich precipitates grow and transform into the thermodynamically stable FCC structure, more $\mathrm{Cu}$ atoms enter the precipitates' core while $\mathrm{Fe}$ atoms are rejected out [9]. The $\mathrm{Ni}, \mathrm{Mn}$, and $\mathrm{Al}$ atoms show a complex behavior. These elements enter the core at the early stages of precipitation and their concentration decreases with further aging [10]. Liu et al. [101] reported that $\mathrm{Mn}$ is more readily to retain in the core as compared with $\mathrm{Ni}$. Jiao et al. [5] pointed out that the presence of $\mathrm{Ni}$ in the $\mathrm{Cu}$-rich core is very important as it can encourage the $\mathrm{Cu}$-rich precipitation by reducing the strain energy nucleation barrier. Many studies showed that the $\mathrm{Cu}$-rich nano-precipitate/matrix interface is wet by diffuse layers or non-uniform shells of $\mathrm{Ni}, \mathrm{Mn}$, and $\mathrm{Al}[9,10,95,96]$. The enrichment of these elements at the interface can come from the solute rejection of both the $\mathrm{Cu}$-rich core and matrix. Isheim et al. [96] pointed out that the elemental segregation is attributed to a thermodynamic driving force, for instance to reduce the interfacial energy that further helps promote the $\mathrm{Cu}$-rich precipitation, and not a consequence of the solute pile-up. The segregation of $\mathrm{Ni}$ and $\mathrm{Mn}$ can be attributed to the positive mixing enthalpy (repulsive interaction) with $\mathrm{Cu}$ while that of $\mathrm{Al}$ to the large negative mixing enthalpy (attractive interaction) with $\mathrm{Ni}$ and $\mathrm{Mn}[5,95]$. As the aging process goes on, the elemental segregation becomes more pronounced and the ordered $\mathrm{B} 2-\mathrm{NiAl}$ phase starts to nucleate and grow heterogeneously at the precipitate/matrix interface, side-byside with the $\mathrm{Cu}$-rich precipitates, forming $\mathrm{Cu} / \mathrm{NiAl}$ coprecipitates $[9,10,94,102]$. The $\mathrm{NiAl}$ precipitation arises from the miscibility gap between the ordered $\mathrm{B} 2-\mathrm{NiAl}$ phase and the disordered BCC Fe in the Fe-Al-Ni alloy system [32]. The NiAl phase has a higher solubility in the BCC Fe than the $\mathrm{Cu}$ atoms [94]. A minimum $2.5 \mathrm{wt} \%$ of $\mathrm{Ni}$ and $1 \mathrm{wt} \%$ of $\mathrm{Al}$ are needed for a successful $\mathrm{NiAl}$ precipitation from the BCC Fe $[22,94]$. The metastable
$\mathrm{NiAl}$ precipitates are not purely $\mathrm{Ni}$ and $\mathrm{Al}$ atoms but contain $\mathrm{Cu}, \mathrm{Mn}, \mathrm{Fe}$ atoms for reducing the lattice misfit strain and thus enhanced precipitation $[7,8,94]$.

According to Jiao et al. [94], these Cu-rich and $\mathrm{NiAl}$ nanoprecipitates can nucleate independently and their precipitation sequence is strongly related to the relative amounts of $\mathrm{Cu}, \mathrm{Ni}$, and $\mathrm{Al}$. In nanostructured steels containing high- $\mathrm{Cu}$ and low-Ni/Al, Cu-rich precipitates will first come out from the supersaturated solid solution followed by the rejection of $\mathrm{Ni}$ and $\mathrm{Al}$ atoms to the surrounding precipitate/matrix interphases. The reversed is true for the nanostructured steels containing low-Cu and high-Ni/Al. The detailed precipitation sequence of the $\mathrm{Cu}$-rich and NiAl precipitates is summarized in Fig. 11 [92]. Xu et al. [103] in Zhang's group also discovered that the additions of Mo can reduce the diffusion coefficient of $\mathrm{Cu}, \mathrm{Ni}$, and $\mathrm{Al}$ atoms and subsequently modify the precipitation sequence of these precipitates.

\section{PRECIPITATE-DISLOCATION INTERACTIONS AND THE STRENGTH- DUCTILITY PARADOX}

The strength and ductility (or toughness) of the nanostructured steels strengthened by a high number density of ultrafine coherent precipitates show a very intriguing behavior. The conventional wisdom taught us that the shearing of coherent precipitates produces a localized slip and deteriorates the ductility significantly $[39,104,105]$. Dislocation looping around non-deformable semi or incoherent particles is more favorable for improved ductility as the slip distribution is more refined and homogenized.

The extremely low room-temperature bending ductility $(<1 \%)$ of the NiAl precipitate-strengthened nanostructured steel (FBB-8) developed by Liaw's group [54] seems to agree with the conventional wisdom. As discussed in the previous sections, the FBB- 8 steel contains duplex-type NiAl precipitates: the relatively large $(\sim 100 \mathrm{~nm}$ in diameter) primary NiAl precipitates and the ultrafine $(\sim 3 \mathrm{~nm}$ in diameter) secondary NiAl precipitates. Sun et al. [54] argued that the brittleness could be ascribed to the ultrafine NiAl precipitates. First, the ultrafine NiAl precipitates could have excessively hardened the steel matrix, resulting in YS higher than the fracture strength of the NiAl precipitates. The NiAl precipitates thus served as crack initiation sites and the cracks could propagate through the steel matrix easily due to the excessive hardening, as shown in Fig. 12. Secondly, the ultrafine NiAl precipitates could also create stress inhomogeneity due to slip localization, in agreement with 


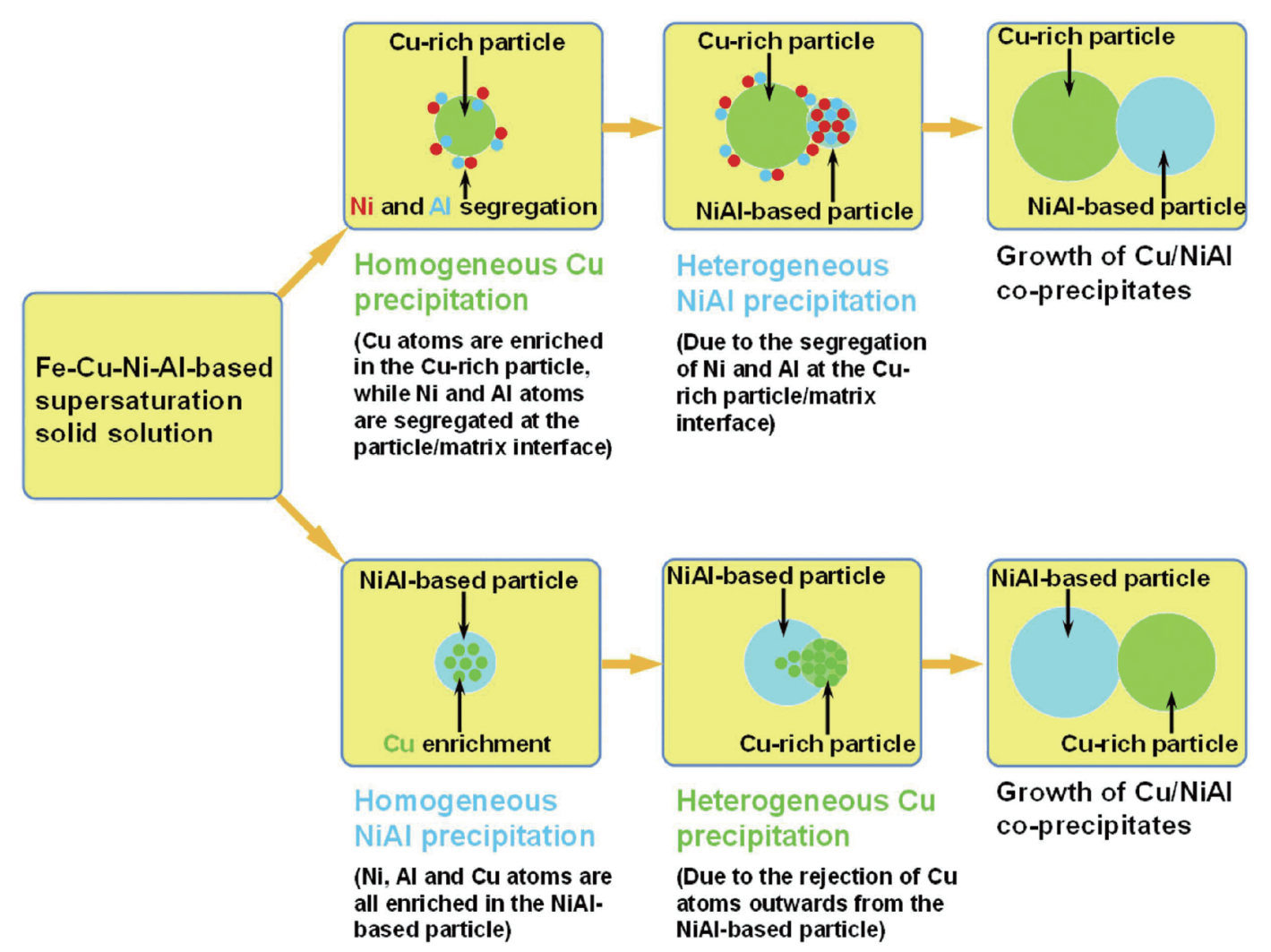

Figure 11 The precipitation sequence of the $\mathrm{Cu}$-rich, $\mathrm{NiAl}$, and $\mathrm{Cu} / \mathrm{NiAl}$ co-precipitates in the advanced nanostructured steel containing $\mathrm{Ni}$, $\mathrm{Al}$, and $\mathrm{Cu}$ additions. The upper sequence indicates $\mathrm{Cu}$-rich precipitation comes before $\mathrm{NiAl}$ in the high-Cu and low-Ni/Al steel while the reverse is true in the low- $\mathrm{Cu}$ and high-Ni/Al steel. Reprinted with permission from Ref. [94]. Copyright 2016, Springer Nature.

the conventional wisdom. Stallybrass et al. [32] also supported that the ultrafine precipitates can lead to reduced ductility due to the restricted dislocation motion in the matrix, as a consequence of reduced interparticle spacing. However, a careful observation on Fig. 12 reveals that the cracks were actually formed at the large primary $\mathrm{NiAl}$ precipitates. Cracks might not have initiated at the ultrafine secondary NiAl precipitates. The dispersion of ultrafine precipitates can restrict the dislocation motion to form a stress concentration and thus raise the stress required for crack nucleation [104]. The brittleness can be a consequence of the easy crack nucleation due to the large primary precipitates. Large precipitates often facilitate a stress concentration and promote the nucleation of cracks [106]. Once the cracks are nucleated at large primary $\mathrm{NiAl}$ precipitates, the cracks propagate easily through the fine dispersion of secondary NiAl precipitates without losing energy [104]. Apart from the size and interparticle spacing, the high-volume fraction of $\mathrm{NiAl}$ precipitates and the increased $\mathrm{Al}$ content in the steel matrix can also contribute to the brittleness $[63,107]$.
On the other hand, the studies from Jiao et al. [5-7], Zhang et al. [11,14], Jiang et al. [8], Kapoor et al. [108] and Vaynman et al. [35] formed another school of thoughts. Their studies suggest that the ultrafine dispersion of high-number-density coherent precipitates can improve strength dramatically with almost no compromise of ductility, breaking the strength-ductility convention. Jiang et al. [8] attributed the ductility enhancement to the stress homogenization due to the ultrafine dispersion of high-number-density coherent precipitates. The high coherency between the precipitate and matrix reduces the strain accumulation and prevents crack initiation as the dislocations shear through the precipitates. Zhang et al. [11] also pointed out the local disordering of the NiAl precipitates due to their offstoichiometric composition [109] and the highly coherent precipitates allow dislocations to shear through easily without a significant change of their Burger's vector [105]. Kapoor et al. [108] suggested the coherent precipitates can serve as a misfit center that encourages the formation of mobile kink segments, helping the disloca- 


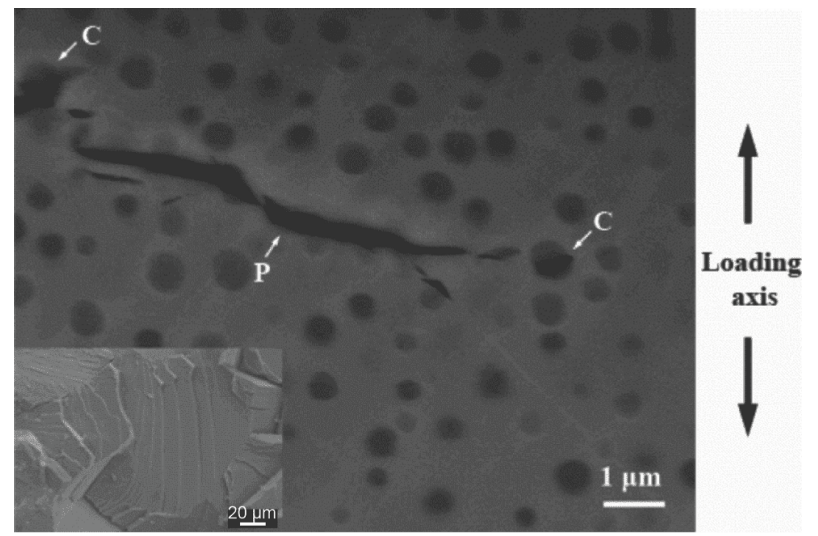

Figure 12 Cracks formed at the large primary $\mathrm{NiAl}$ precipitates and propagated through the hardened matrix. The fractured surface is shown in the inset. C: cracks; P: crack propagation. Reprinted with permission from Ref. [54]. Copyright 2015, Taylor and Francis.

tions to move out from the Peierls valley easily [110]. The recent in-situ neutron diffraction analyses from Zhang's group [14] also revealed that the fine dispersion of nanoscale coherent precipitates can encourage simultaneous rotation of multiple crystal planes during deformation, leading to a better stress transfer and therefore enhanced ductility.

\section{CURRENT LIMITATION AND FUTURE DEVELOPMENT}

For the widespread use of the low-carbon advanced nanostructured steels in various engineering applications, the cost is always a main concern. The new advanced nanostructured steels must be cost-competitive in order to attract better market volume. This can be achieved by optimizing the steel chemistry, for example, by substituting the expensive elements such as nickel $(\mathrm{Ni})$ and molybdenum (Mo) with cheaper elements. Carbon is a potent and cost-effective solid solution strengthener in steels [111]. However, an addition of too much carbon will reduce the toughness of the steels. A thorough study on the effects of carbon on the mechanical properties of nanostructured steels is needed. Despite the successful development of ductile advanced nanostructured steels with tensile strengths approaching $2 \mathrm{GPa}$, there is still plenty of room for strength improvement as heavily cold drawn pearlitic wires can achieve tensile strengths as high as $7 \mathrm{GPa}[112,113]$. Most of the recent nanostructured steels are developed based on the dislocation shearing mechanism. Dislocation looping is another strengthening mechanism that can lead to a strength improvement. The looping mechanism was observed in steels strengthened with a relatively low number density $\left(\sim 10^{20} \mathrm{~m}^{-3}\right)$ and large non-deformable NiAl precipitates $(\sim 50 \mathrm{~nm})$ [54]. The possibilities of obtaining strong yet ductile nanostructured steels by incorporating both mechanisms remain unknown. Alloying the nanostructured steels with appropriate $\mathrm{Mn}$ additions is another cheap yet effective solution for an enhanced strength-ductility balance as discussed in the text earlier. It is widely recognized that the Mn additions can stabilize the austenite phase. The austenite phase undergoes a gradual martensitic transformation during deformation and contributes to an enhanced ductility through a progressive TRIP effect. It was also reported by Raabe and co-workers $[114,115]$ that the $\mathrm{Mn}$ additions can lead to the formation of linear complexions through the Mn segregation confined at the dislocation cores. By altering the chemistry and structure of these linear complexions, it is possible to control the mobility of the dislocations and thereby provide a new approach to the development of nanostructured steels with an improved strength-ductility balance [116]. A similar ductilizing mechanism through manipulating the elemental segregation to form disordered nanolayers at the grain boundaries of the conventionally brittle longrange-ordered superlattice alloys was also demonstrated by Yang et al. [117] recently.

The embrittlement of nanostructured steels is still not fully resolved at the present time. The nanostructured steels can achieve an excellent impact toughness $(\sim 200 \mathrm{~J})$ even at low temperatures $\left(-40^{\circ} \mathrm{C}\right)$ while maintaining their room temperature YS at around $1 \mathrm{GPa}$ by annealing beyond the embrittlement regime $\left(300-600^{\circ} \mathrm{C}\right)$ followed by fast quenching. However, more work is still needed as the nanostructured steels with a higher YS are generally required to be annealed at temperatures $\left(400-550^{\circ} \mathrm{C}\right)$ within the embrittlement regime. In applications that require service temperatures between $300-600^{\circ} \mathrm{C}$, the nanostructured steels will still face the embrittlement problem as embrittling elements segregate back into the prior-austenite grain boundaries. Besides, the embrittling elements will also have a chance to get into the prioraustenite grain boundaries during the cooling stage after welding, especially in thick samples, reducing the impact toughness of the steels. One possible way to alleviate this problem will be adding boron (B) into the steels. Boron can delay the embrittlement by segregating into the prioraustenite grain boundaries during high temperature quenching through non-equilibrium segregation [118]. The segregation of $B$ at the prior-austenite grain boundaries will reduce the interfacial energy and thus decrease the segregation of embrittling elements. Another possible 
way will be the design of steel chemistry so that a soft austenite phase exists, but at the expense of the steel strength generally $[65,81,119-123]$. Steels with ultrafine grains are also expected to demonstrate improved toughness as the dislocation pile-up and crack propagation become more difficult, in addition to the reduced segregation of embrittling elements at grain boundaries [124-127]. Controlling the structure of the grain boundaries through grain-boundary engineering can also help in minimizing the segregation of embrittling elements $[120,128,129]$. Recent studies also suggest a more relaxed grain boundary structure [130-132] and the presence of intergranular amorphous film $[133,134]$ are beneficial to toughness improvement. Heterogeneous columnar-type grains were also reported to be effective in suppressing crack propagation [135].

Weldability is another important issue when it comes to the real applications of nanostructured steels. The advanced nanostructured steels contain low-carbon and display superior weldability without causing any cracks [19]. However, the nanostructured steels often experience precipitate dissolution in the fusion zone during the welding process, leading to joint softening. A post-weld heat treatment is required to recover the strength of the joint and this translates into an additional cost. Based on the welding experiment by Jiao et al. [19], a simple post weld heat treatment at $600^{\circ} \mathrm{C}$ for $30 \mathrm{~min}$ can successfully recover the $\mathrm{YS}$ of the $\mathrm{Cu} / \mathrm{NiAl}$ co-precipitate-strengthened low-carbon nanostructured steel from $790 \mathrm{MPa}$ in the as-weld condition to $1460 \mathrm{MPa}$ (by $87 \%$ ) with satisfactory ductility. On the other hand, the development of a unique welding technique that minimizes the microstructural damage without the need of post-weld heat treatments is also highly desirable, especially important for large-scale infrastructures and future advanced nanostructured steels with thinner gauges. In line with this, Chen et al. [20] demonstrated that the nanostructured steels with the combined $\mathrm{Cu}$ and $\mathrm{Mn}$ additions show excellent weldability with satisfactory strength and ductility through a magnetic field-assisted laser welding without the subsequent post-weld heat treatments. Moreover, due to the low precipitate dissolution temperature, the nanostructured steels show a limited creep resistance in applications with service temperatures above $700^{\circ} \mathrm{C}[69]$. By incorporating misfit strains at the precipitate/matrix interface, it is possible to enhance the creep resistance to even comparable to the Haynes 282 Ni-based superalloys [69]. It is also very intriguing to note that the grain boundaries decorated with multi-elemental segregation display an exceptional resistance to coarsen- ing even at high temperatures [117]. Coherent boundaries are also known to exhibit extraordinary thermal stability [136-138], and all of these can open up new opportunities for the development of high-temperature steels.

\section{CONCLUSION}

In essence, the recently developed high-strength steels rely heavily on a high level of carbon additions which often lead to inferior weldability. This paper reviews the recent development of low-carbon advanced nanostructured steels strengthened by coherent $\mathrm{Cu}$-rich and $\mathrm{NiAl}$ nano-precipitates. These advanced nanostructured steels possess a low production cost, excellent strengthductility balance, superior weldability, good fabricability, and high impact toughness even at a temperature as low as $-40^{\circ} \mathrm{C}$; thus, they are well suited for various engineering applications. An exceptional strength-ductility balance can be obtained by adding $\mathrm{Mn}$ for the formation of complex heterogeneous multiphase grain structures with ultrafine coherent nano-precipitates. The development of strong ( $\mathrm{YS}>2 \mathrm{GPa}$ ) yet ductile (tensile elongation to $10 \%)$ and low-cost advanced nanostructured steels with a good weldability that can potentially serve in both high temperature $\left(>700^{\circ} \mathrm{C}\right)$ and cryogenic $\left(<-40^{\circ} \mathrm{C}\right)$ applications for the steel industry will be the focus on the future research direction.

Received 9 September 2020; accepted 25 December 2020; published online 17 March 2021

1 Bhadeshia HKDH. The first bulk nanostructured metal. Sci Tech Adv Mater, 2013, 14: 014202

2 Miller RL. Ultrafine-grained microstructures and mechanical properties of alloy steels. Metall Trans, 1972, 3: 905-912

3 Halfa H. Recent trends in producing ultrafine grained steels. J Min Mater Charact Eng, 2014, 02: 428-469

4 Garcia-Mateo C, Caballero FG, Bhadeshia HKDH. Development of hard bainite. ISIJ Int, 2003, 43: 1238-1243

5 Jiao ZB, Luan JH, Zhang ZW, et al. Synergistic effects of $\mathrm{Cu}$ and $\mathrm{Ni}$ on nanoscale precipitation and mechanical properties of highstrength steels. Acta Mater, 2013, 61: 5996-6005

6 Jiao ZB, Luan JH, Miller MK, et al. Precipitation mechanism and mechanical properties of an ultra-high strength steel hardened by nanoscale $\mathrm{NiAl}$ and $\mathrm{Cu}$ particles. Acta Mater, 2015, 97: 58-67

7 Jiao ZB, Luan JH, Miller MK, et al. Effects of Mn partitioning on nanoscale precipitation and mechanical properties of ferritic steels strengthened by NiAl nanoparticles. Acta Mater, 2015, 84: 283-291

8 Jiang $\mathrm{S}$, Wang $\mathrm{H}, \mathrm{Wu} \mathrm{Y}$, et al. Ultrastrong steel via minimal lattice misfit and high-density nanoprecipitation. Nature, 2017, 544: $460-464$

9 Kapoor M, Isheim D, Ghosh G, et al. Aging characteristics and mechanical properties of $1600 \mathrm{MPa}$ body-centered cubic $\mathrm{Cu}$ and B2-NiAl precipitation-strengthened ferritic steel. Acta Mater, 2014, 73: 56-74 
10 Kolli RP, Seidman DN. The temporal evolution of the decomposition of a concentrated multicomponent $\mathrm{Fe}-\mathrm{Cu}$-based steel. Acta Mater, 2008, 56: 2073-2088

11 Zhang Z, Liu CT, Miller MK, et al. A nanoscale co-precipitation approach for property enhancement of Fe-base alloys. Sci Rep, 2013, 3: 1327

12 Gagliano MS, Fine ME. Characterization of the nucleation and growth behavior of copper precipitates in low-carbon steels. Metall Mat Trans A, 2004, 35: 2323-2329

13 Jiao ZB, Luan JH, Miller MK, et al. Co-precipitation of nanoscale particles in steels with ultra-high strength for a new era. Mater Today, 2017, 20: 142-154

$14 \mathrm{Xu} \mathrm{SS}$, Li JP, Cui Y, et al. Mechanical properties and deformation mechanisms of a novel austenite-martensite dual phase steel. Int J Plast, 2020, 128: 102677

15 Zhou BC, Yang T, Zhou G, et al. Mechanisms for suppressing discontinuous precipitation and improving mechanical properties of NiAl-strengthened steels through nanoscale $\mathrm{Cu}$ partitioning. Acta Mater, 2021, 205: 116561

16 Li Y, Li W, Xu C, et al. Investigation of hierarchical precipitation on bimodal-grained austenite and mechanical properties in quenching-partitioning-tempering steel. Mater Sci Eng-A, 2020, 781: 139207

17 Li Y, Li W, Min N, et al. Homogeneous elasto-plastic deformation and improved strain compatibility between austenite and ferrite in a co-precipitation hardened medium $\mathrm{Mn}$ steel with enhanced hydrogen embrittlement resistance. Int J Plast, 2020, 133: 102805

18 Kong HJ, Yang T, Chen R, et al. Breaking the strength-ductility paradox in advanced nanostructured Fe-based alloys through combined $\mathrm{Cu}$ and $\mathrm{Mn}$ additions. Scripta Mater, 2020, 186: 213218

19 Jiao ZB, Luan JH, Guo W, et al. Effects of welding and post-weld heat treatments on nanoscale precipitation and mechanical properties of an ultra-high strength steel hardened by $\mathrm{NiAl}$ and $\mathrm{Cu}$ nanoparticles. Acta Mater, 2016, 120: 216-227

20 Chen R, Kong HJ, Luan JH, et al. Effect of external applied magnetic field on microstructures and mechanical properties of laser welding joint of medium-Mn nanostructured steel. Mater Sci Eng-A, 2020, 792: 139787

21 Isheim D, Kolli RP, Fine ME, et al. An atom-probe tomographic study of the temporal evolution of the nanostructure of $\mathrm{Fe}-\mathrm{Cu}$ based high-strength low-carbon steels. Scripta Mater, 2006, 55: $35-40$

22 Jiao ZB, Luan JH, Zhang ZW, et al. High-strength steels hardened mainly by nanoscale NiAl precipitates. Scripta Mater, 2014, 87: $45-48$

23 Zhang ZW, Liu CT, Wang XL, et al. Effects of proton irradiation on nanocluster precipitation in ferritic steel containing fcc alloying additions. Acta Mater, 2012, 60: 3034-3046

24 Busby J. NEET-Nuclear Energy Enabling Technologies Reactor Materials. News for the reactor materials crosscut. US Department of Energy, May 2015. [Online]. Available at: https://www. energy.gov/sites/prod/files/2015/08/f25/NEET-Reactor\%20Materials\%20Newsletter\%20-\%20Issue\%201.pdf

25 Vaynman S, Fine ME, Ghosh G, et al. Copper precipitation hardened, high strength, weldable steels. In: The Proceedings of the 4th Materials Engineering Conference: Materials for the New Millennium. Washington, 1996, 10-14

26 Liu Q, Liu W, Xiong X. Correlation of $\mathrm{Cu}$ precipitation with austenite-ferrite transformation in a continuously cooled multi- component steel: An atom probe tomography study. J Mater Res, 2012, 27: 1060-1067

27 World Steel Association. Future steel vehicle results and reports \& cost model. World Auto Steel, Feb 2020. [Online]. Available: https://www.worldautosteel.org/projects/future-steel-vehicle/ phase-2-results/

28 Roland F, Manzon L, Kujala P, et al. Advanced joining techniques in European shipbuilding. J Ship Prod, 2004, 20: 200-210

$29 \mathrm{He} \mathrm{BB}, \mathrm{Hu} \mathrm{B}$, Yen HW, et al. High dislocation density-induced large ductility in deformed and partitioned steels. Science, 2017, 357: 1029-1032

30 Liu L, Yu Q, Wang Z, et al. Making ultrastrong steel tough by grain-boundary delamination. Science, 2020, 368: 1347-1352

31 Raabe D, Ponge D, Dmitrieva O, et al. Nanoprecipitate-hardened 1.5 GPa steels with unexpected high ductility. Scripta Mater, 2009, 60: 1141-1144

32 Stallybrass C, Schneider A, Sauthoff G. The strengthening effect of $(\mathrm{Ni}, \mathrm{Fe}) \mathrm{Al}$ precipitates on the mechanical properties at high temperatures of ferritic $\mathrm{Fe}-\mathrm{Al}-\mathrm{Ni}-\mathrm{Cr}$ alloys. Intermetallics, 2005, 13: $1263-1268$

33 Vaynman S, Fine ME, Bhat SP. High strength copper steel for rail tank cars to bridges. Copper Development Association Inc., December 2006. [Online]. Available: https://www.copper.org/publications/newsletters/innovations/2006/12/high_strength_cu_ steel.html

34 Vaynman S, Fine ME, Chung YW. Super-tough steel for bridges and other applications. Center for the Commercialization of Innovative Transportation Technology, USDOT University Transportation Center, 2009

35 Vaynman S, Isheim D, Prakash Kolli R, et al. High-strength lowcarbon ferritic steel containing $\mathrm{Cu}-\mathrm{Fe}-\mathrm{Ni}-\mathrm{Al}-\mathrm{Mn}$ precipitates. Metall Mat Trans A, 2008, 39: 363-373

36 Kolli RP, Seidman DN. Heat treatment of copper precipitationstrengthened steels. In: Dossett JL, Totten GE. ASM Handbook. Volume 4D. Heat Treating of Irons and Steels. Phoenix: ASM International, 2014. 188-203

37 Fine M, Vaynman S. Monitoring and advising on Lave Villa Bridge. Northwestern University Libraries, 2007

38 Kolli RP, Seidman DN. Co-precipitated and collocated carbides and $\mathrm{Cu}$-rich precipitates in a $\mathrm{Fe}$ - $\mathrm{Cu}$ steel characterized by atomprobe tomography. Microsc Microanal, 2014, 20: 1727-1739

39 Martin JW. Precipitation Hardening. Oxford: ButterworthHeinemann, 1998

40 Klamecki B. Chapter 19: Cold-working process. University of Minnesota, 2002. [Online]. Available: http://www.menet.umn. edu/ klamecki/degarmo/

41 Bhadeshia HKDH. TRIP-assisted steels? ISIJ Int, 2002, 42: 10591060

42 Marquis EA, Choi PP, Danoix F, et al. New insights into the atomic-scale structures and behavior of steels. Micros Today, 2012, 20: 44-48

43 Ryu JH, Kim DI, Kim HS, et al. Strain partitioning and mechanical stability of retained austenite. Scripta Mater, 2010, 63: 297-299

44 Zhu YT, Wu XL. Ductility and plasticity of nanostructured metals: Differences and issues. Mater Today Nano, 2018, 2: 15-20

45 Yang MX, Yuan FP, Xie QG, et al. Strain hardening in Fe-16Mn10Al-0.86C-5Ni high specific strength steel. Acta Mater, 2016, 109: $213-222$

46 Lee S, Lee SJ, De Cooman BC. Work hardening behavior of ul- 
trafine-grained $\mathrm{Mn}$ transformation-induced plasticity steel. Acta Mater, 2011, 59: 7546-7553

47 Sun B, Fazeli F, Scott C, et al. Critical role of strain partitioning and deformation twinning on cracking phenomenon occurring during cold rolling of two duplex medium manganese steels. Scripta Mater, 2017, 130: 49-53

48 Liu XL, Xue QQ, Wang W, et al. Back-stress-induced strengthening and strain hardening in dual-phase steel. Materialia, 2019, 7: 100376

49 Wu X, Zhu Y. Heterogeneous materials: A new class of materials with unprecedented mechanical properties. Mater Res Lett, 2017, 5: 527-532

50 Lu K. Making strong nanomaterials ductile with gradients. Science, 2014, 345: 1455-1456

$51 \mathrm{Wu}$ XL, Jiang $\mathrm{P}$, Chen $\mathrm{L}$, et al. Synergetic strengthening by gradient structure. Mater Res Lett, 2014, 2: 185-191

52 Tan X, Ponge D, Lu W, et al. Joint investigation of strain partitioning and chemical partitioning in ferrite-containing TRIPassisted steels. Acta Mater, 2020, 186: 374-388

53 Tan X, Ponge D, Lu W, et al. Carbon and strain partitioning in a quenched and partitioned steel containing ferrite. Acta Mater, 2019, 165: 561-576

54 Sun Z, Song G, Ilavsky J, et al. Duplex precipitates and their effects on the room-temperature fracture behaviour of a NiAlstrengthened ferritic alloy. Mater Res Lett, 2015, 3: 128-134

55 Seetharaman V, Sundararaman M, Krishnan R. Precipitation hardening in a PH 13-8 Mo stainless steel. Mater Sci Eng, 1981, 47: $1-11$

56 Taillard R, Pineau A, Thomas BJ. The precipitation of the intermetallic compound $\mathrm{NiAl}$ in $\mathrm{Fe}-19$ wt\% Cr alloys. Mater Sci Eng, 1982, 54: 209-219

57 Taillard R, Pineau A. Room temperature tensile properties of $\mathrm{Fe}-19 \mathrm{wt} \% \mathrm{Cr}$ alloys precipitation hardened by the intermetallic compound NiAl. Mater Sci Eng, 1982, 56: 219-231

58 Guo Z, Sha W, Vaumousse D. Microstructural evolution in a PH 13-8 stainless steel after ageing. Acta Mater, 2003, 51: 101-116

59 Leitner H, Schober M, Schnitzer R. Splitting phenomenon in the precipitation evolution in an $\mathrm{Fe}-\mathrm{Ni}$-Al-Ti-Cr stainless steel. Acta Mater, 2010, 58: 1261-1269

60 Niu M, Zhou G, Wang W, et al. Precipitate evolution and strengthening behavior during aging process in a $2.5 \mathrm{GPa}$ grade maraging steel. Acta Mater, 2019, 179: 296-307

61 Sun Z, Song G, Ilavsky J, et al. Nano-sized precipitate stability and its controlling factors in a NiAl-strengthened ferritic alloy. Sci Rep, 2015, 5: 16081

62 Teng ZK, Miller MK, Ghosh G, et al. Characterization of nanoscale NiAl-type precipitates in a ferritic steel by electron microscopy and atom probe tomography. Scripta Mater, 2010, 63: 6164

63 Teng ZK, Liu CT, Ghosh G, et al. Effects of $\mathrm{Al}$ on the microstructure and ductility of NiAl-strengthened ferritic steels at room temperature. Intermetallics, 2010, 18: 1437-1443

64 Erlach SD, Leitner $\mathrm{H}$, Bischof $\mathrm{M}$, et al. Comparison of NiAl precipitation in a medium carbon secondary hardening steel and C-free PH 13-8 maraging steel. Mater Sci Eng-A, 2006, 429: 96106

65 Sha W, Leitner H, Guo Z, et al. Phase transformations in maraging steels. In: Pereloma E, Edmonds DV (Eds). Phase Transformations in Steels: Diffusionless Transformations, High Strength Steels, Modelling and Advanced Analytical Techniques.
Volume 2 in Woodhead Publishing Series in Metals and Surface Engineering. Cambridge: Woodhead Publishing Limited, 2012. 332-362

66 Sun L, Simm TH, Martin TL, et al. A novel ultra-high strength maraging steel with balanced ductility and creep resistance achieved by nanoscale $\beta-\mathrm{NiAl}$ and Laves phase precipitates. Acta Mater, 2018, 149: 285-301

67 Hulme-Smith CN, Bhadeshia HKDH. Mechanical properties of thermally-stable, nanocrystalline bainitic steels. Mater Sci Eng-A, 2017, 700: 714-720

68 Simm TH, Sun L, Galvin DR, et al. The effect of a two-stage heattreatment on the microstructural and mechanical properties of a maraging steel. Materials, 2017, 10: 1346

69 Song G, Sun Z, Li L, et al. Ferritic alloys with extreme creep resistance via coherent hierarchical precipitates. Sci Rep, 2015, 5: 16327

70 Teng ZK, Zhang F, Miller MK, et al. New NiAl-strengthened ferritic steels with balanced creep resistance and ductility designed by coupling thermodynamic calculations with focused experiments. Intermetallics, 2012, 29: 110-115

71 Calderon HA, Fine ME, Weertman JR. Coarsening and morphology of $\beta^{\prime}$ particles in Fe-Ni-Al-Mo ferritic alloys. Metall Trans A, 1988, 19: 1135-1146

72 Base Metals Investing-Prices, Mining Stocks and News. Glacier Media Group, Oct 2019. [Online]. Available: http://www.infomine.com/investment/base-metals/

73 Pig Iron. SMM Information \& Technology Co., Ltd., Oct 2019. [Online]. Available: https://price.metal.com/Pig-Iron

74 Duan QQ, Qu RT, Zhang P, et al. Intrinsic impact toughness of relatively high strength alloys. Acta Mater, 2018, 142: 226-235

75 Bandyopadhyay N, McMahon CJ. The micro-mechanisms of tempered martensite embrittlement in 4340-type steels. Metall Trans A, 1983, 14: 1313-1325

76 Basinski ZS, Christian JW. Mechanical properties of metals at low temperatures. In: Timmerhaus KD (Ed). Advances in Cryogenic Engineering. Advances in Cryogenic Engineering, vol 2. Boston: Springer, 1960

77 Kwon KH, Yi IC, Ha Y, et al. Origin of intergranular fracture in martensitic $8 \mathrm{Mn}$ steel at cryogenic temperatures. Scripta Mater, 2013, 69: 420-423

78 Horn RM, Ritchie RO. Mechanisms of tempered martensite embrittlement in low alloy steels. Metall Trans A, 1978, 9: 10391053

79 Seah MP. Interface adsorption, embrittlement and fracture in metallurgy. Surf Sci, 1975, 53: 168-212

80 Dhua SK, Ray A, Sarma DS. Effect of tempering temperatures on the mechanical properties and microstructures of HSLA-100 type copper-bearing steels. Mater Sci Eng-A, 2001, 318: 197-210

81 Liu Q, Wen $\mathrm{H}$, Zhang $\mathrm{H}$, et al. Effect of multistage heat treatment on microstructure and mechanical properties of high-strength low-alloy steel. Metall Mat Trans A, 2016, 47: 1960-1974

82 Kong $\mathrm{HJ}, \mathrm{Xu} \mathrm{C}, \mathrm{Bu} \mathrm{CC}$, et al. Hardening mechanisms and impact toughening of a high-strength steel containing low $\mathrm{Ni}$ and $\mathrm{Cu}$ additions. Acta Mater, 2019, 172: 150-160

83 Shin SY, Hwang B, Lee S, et al. Correlation of microstructure and charpy impact properties in API X70 and X80 line-pipe steels. Mater Sci Eng-A, 2007, 458: 281-289

84 Zhao Y, Tong X, Wei XH, et al. Effects of microstructure on crack resistance and low-temperature toughness of ultra-low carbon high strength steel. Int J Plast, 2019, 116: 203-215 
85 Han G, Xie ZJ, Li ZY, et al. Evolution of crystal structure of Cu precipitates in a low carbon steel. Mater Des, 2017, 135: 92-101

86 Monzen R, Jenkins ML, Sutton AP. The bcc-to-9R martensitic transformation of $\mathrm{Cu}$ precipitates and the relaxation process of elastic strains in an Fe-Cu alloy. Philos Mag A, 2000, 80: 711-723

87 Sun M, Zhang W, Liu Z, et al. Direct observations on the crystal structure evolution of nano Cu-precipitates in an extremely low carbon steel. Mater Lett, 2017, 187: 49-52

88 Othen PJ, Jenkins ML, Smith GDW, et al. Transmission electron microscope investigations of the structure of copper precipitates in thermally-aged $\mathrm{Fe}-\mathrm{Cu}$ and $\mathrm{Fe}-\mathrm{Cu}-\mathrm{Ni}$. Philos Mag Lett, 1991, 64: 383-391

89 Takahashi J, Kawakami K, Kobayashi Y. Consideration of particle-strengthening mechanism of copper-precipitation-strengthened steels by atom probe tomography analysis. Mater Sci Eng-A, 2012, 535: 144-152

90 Lozano-Perez S, Jenkins ML, Titchmarsh JM. Evidence for deformation-induced transformations of $\mathrm{Cu}$-rich precipitates in an aged FeCu alloy. Philos Mag Lett, 2006, 86: 367-374

91 Hu SY, Schmauder S, Chen LQ. Atomistic simulations of interactions between $\mathrm{Cu}$ precipitates and an edge dislocation in a BCC Fe single crystal. Phys Stat Sol B, 2000, 220: 845-846

92 Sun Z. Microstructures and mechanical behavior of NiAlstrengthened ferritic alloys at room and elevated temperatures. Dissertation for the Doctoral Degree. Tennessee: University of Tennessee, 2015

93 Liu CT, Jiao ZB, Luan JH. Copper-rich nanoclusters: Ferritic steels strengthened. In: Colás R, Totten GE (Eds). Encyclopedia of Iron, Steel, and Their Alloys. Florida: CRC Press, 2015. 875-886

94 Jiao ZB, Luan JH, Miller MK, et al. Group precipitation and age hardening of nanostructured Fe-based alloys with ultra-high strengths. Sci Rep, 2016, 6: 21364

95 Wen YR, Hirata A, Zhang ZW, et al. Microstructure characterization of $\mathrm{Cu}$-rich nanoprecipitates in a $\mathrm{Fe}-2.5 \mathrm{Cu}-1.5 \mathrm{Mn}-4.0 \mathrm{Ni}$ 1.0Al multicomponent ferritic alloy. Acta Mater, 2013, 61: 21332147

96 Isheim D, Gagliano MS, Fine ME, et al. Interfacial segregation at $\mathrm{Cu}$-rich precipitates in a high-strength low-carbon steel studied on a sub-nanometer scale. Acta Mater, 2006, 54: 841-849

97 Fine ME, Liu JZ, Asta MD. An unsolved mystery: The composition of bcc $\mathrm{Cu}$ alloy precipitates in bcc Fe and steels. Mater Sci Eng-A, 2007, 463: 271-274

98 Worrall GM, Buswell JT, English CA, et al. A study of the precipitation of copper particles in a ferrite matrix. J Nucl Mater, 1987, 148: 107-114

99 Osamura K, Okuda H, Takashima M, et al. Small-angle neutron scattering study of phase decomposition in $\mathrm{Fe}-\mathrm{Cu}$ binary alloy. Mater Trans JIM, 1993, 34: 305-311

100 Zhu J, Zhang T, Yang Y, et al. Phase field study of the copper precipitation in Fe-Cu alloy. Acta Mater, 2019, 166: 560-571

101 Liu Q, Chen Y, Li C, et al. Compositional variants of Cu-rich precipitate in thermally aged ferritic steel. Acta Metall Sin (Engl Lett), 2018, 31: 465-470

102 Kolli RP, Mao Z, Seidman DN, et al. Identification of a $\mathrm{Ni}_{0.5}\left(\mathrm{Al}_{0.5-} \mathrm{Mn}_{x}\right) \mathrm{B}_{2}$ phase at the heterophase interfaces of $\mathrm{Cu}$-rich precipitates in an a-Fe matrix. Appl Phys Lett, 2007, 91: 241903

103 Xu SS, Liu YW, Zhang Y, et al. Precipitation kinetics and mechanical properties of nanostructured steels with Mo additions. Mater Res Lett, 2020, 8: 187-194

104 Martin JW. Micromechanisms in Particle-Hardened Alloys. Great
Britian: Cambridge University Press, 1980

105 Hornbogen E, Zum Gahr KH. Distribution of plastic strain in alloys containing small particles. Metallography, 1975, 8: 181-202

106 Baker I. Improving the ductility of intermetallic compounds by particle-induced slip homogenization. Scr Mater, 1999, 41: 109414

107 Teng ZK, Liu CT, Miller MK, et al. Room temperature ductility of NiAl-strengthened ferritic steels: Effects of precipitate microstructure. Mater Sci Eng-A, 2012, 541: 22-27

108 Kapoor M, Isheim D, Vaynman S, et al. Effects of increased alloying element content on NiAl-type precipitate formation, loading rate sensitivity, and ductility of $\mathrm{Cu}$ - and NiAl-precipitation-strengthened ferritic steels. Acta Mater, 2016, 104: 166-171

109 Stoloff NS, Davies RG. The mechanical properties of ordered alloys. Prog Mater Sci, 1968, 13: 1-84

110 Fine ME, Vaynman S, Isheim D, et al. A new paradigm for designing high-fracture-energy steels. Metall Mat Trans A, 2010, 41: 3318-3325

111 Honeycombe RWK, Bhadeshia HKDH. Steels: Microstructure and Properties. London: Edward Arnold, 1995

112 Li Y, Raabe D, Herbig M, et al. Segregation stabilizes nanocrystalline bulk steel with near theoretical strength. Phys Rev Lett, 2014, 113: 106104

113 Morris JW, Guo Z, Krenn CR, et al. Advances in physical metallurgy and processing of steels. The limits of strength and toughness in steel. ISIJ Int, 2001, 41: 599-611

114 Kuzmina M, Herbig M, Ponge D, et al. Linear complexions: Confined chemical and structural states at dislocations. Science, 2015, 349: 1080-1083

115 Kwiatkowski da Silva A, Leyson G, Kuzmina M, et al. Confined chemical and structural states at dislocations in Fe-9wt\% $\mathrm{Mn}$ steels: A correlative TEM-atom probe study combined with multiscale modelling. Acta Mater, 2017, 124: 305-315

116 Kaplan WD. The mechanism of crystal deformation. Science, 2015, 349: 1059-1060

117 Yang T, Zhao YL, Li WP. Ultrahigh-strength and ductile superlattice alloys with nanoscale disordered interfaces. Science, 2020, 369: 427-432

118 Kuzmina M, Ponge D, Raabe D. Grain boundary segregation engineering and austenite reversion turn embrittlement into toughness: Example of a $9 \mathrm{wt} \%$ medium Mn steel. Acta Mater, 2015, 86: 182-192

119 Kong H, Liu C. A review on nano-scale precipitation in steels. Technologies, 2018, 6: 36

120 Raabe D, Herbig M, Sandlöbes S, et al. Grain boundary segregation engineering in metallic alloys: A pathway to the design of interfaces. Curr Opin Solid State Mater Sci, 2014, 18: 253-261

121 Li DZ, Wei YH, Hou LF, et al. Effect of temperature on impact properties and microstructural evolution of twinning induced plasticity steel. Mater Sci Tech, 2012, 28: 303-310

122 Sugimoto K, Srivastava AK. Microstructure and mechanical properties of a TRIP-aided martensitic steel. Metallogr Microstruct Anal, 2015, 4: 344-354

123 Zou Y, Xu YB, Wang G, et al. Improved strength-ductilitytoughness balance of a precipitation-strengthened low-carbon medium-Mn steel by adopting intercritical annealing-tempering process. Mater Sci Eng-A, 2021, 802: 140636

124 Song R, Ponge D, Raabe D. Mechanical properties of an ultrafine grained C-Mn steel processed by warm deformation and annealing. Acta Mater, 2005, 53: 4881-4892 
125 Ishida K. Effect of grain size on grain boundary segregation. J Alloys Compd, 1996, 235: 244-249

126 Hou W, Liu Q, Gu J. Improved impact toughness by multi-step heat treatment in a $1400 \mathrm{MPa}$ low carbon precipitationstrengthened steel. Mater Sci Eng-A, 2020, 797: 140077

127 Armstrong RW. Dislocation pile-ups, strength properties and fracturing. Rev Adv Mater Sci, 2017, 48: 1-12

128 Lejček P, Hofmann S, Paidar V. Solute segregation and classification of [100] tilt grain boundaries in a-iron: Consequences for grain boundary engineering. Acta Mater, 2003, 51: 3951-3963

129 Watanabe T. Grain boundary design and control for high temperature materials. Mater Sci Eng-A, 1993, 166: 11-28

130 Jang D, Atzmon M. Grain-boundary relaxation and its effect on plasticity in nanocrystalline Fe. J Appl Phys, 2006, 99: 083504

131 Rupert TJ, Trelewicz JR, Schuh CA. Grain boundary relaxation strengthening of nanocrystalline Ni-W alloys. J Mater Res, 2012, 27: 1285-1294

$132 \mathrm{Lu} \mathrm{K}, \mathrm{Lu} \mathrm{L}$, Suresh S. Strengthening materials by engineering coherent internal boundaries at the nanoscale. Science, 2009, 324: 349-352

133 Pan Z, Rupert TJ. Amorphous intergranular films as toughening structural features. Acta Mater, 2015, 89: 205-214

134 Khalajhedayati A, Pan Z, Rupert TJ. Manipulating the interfacial structure of nanomaterials to achieve a unique combination of strength and ductility. Nat Commun, 2016, 7: 10802

135 Cao BX, Kong HJ, Fan L, et al. Heterogenous columnar-grained high-entropy alloys produce exceptional resistance to intermediate-temperature intergranular embrittlement. Scripta Mater, 2021, 194: 113622

136 Anderoglu O, Misra A, Wang $\mathrm{H}$, et al. Thermal stability of sputtered $\mathrm{Cu}$ films with nanoscale growth twins. J Appl Phys, 2008, 103: 094322

137 Zhang X, Misra A. Superior thermal stability of coherent twin boundaries in nanotwinned metals. Scripta Mater, 2012, 66: 860865

138 Zhou X, Li XY, Lu K. Stabilizing nanograins in metals with grain boundary relaxation. Scripta Mater, 2020, 187: 345-349

139 Tempelman E. Lightweight materials, lightweight design? In: Karana E, Pedgley O, Rognoli V (Eds). Materials Experience: Fundamentals of Materials and Design. Boston: Elsevier, 2014. 247-258

140 Wen YR, Li YP, Hirata A, et al. Synergistic alloying effect on microstructural evolution and mechanical properties of $\mathrm{Cu}$ precipitation-strengthened ferritic alloys. Acta Mater, 2013, 61: 7726-7740

Acknowledgements This work was supported by the National Natural Science Foundation of China (51801169), Hong Kong Research Grant Council (CityU Grant 9360161, 9042635, 9042879), and the internal funding from the City University of Hong Kong (CityU 9380060).

Author contributions Kong HJ and Liu CT wrote the manuscript; Liu $\mathrm{CT}$ and Jiao ZB conceptualized the idea; Lu J and Liu CT acquired the funding.

Conflict of interest The authors declare that they have no conflict of interest.

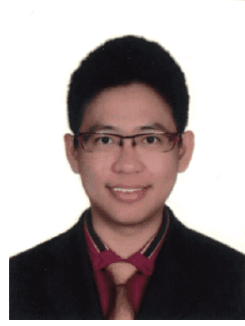

Haojie Kong obtained his $\mathrm{PhD}$ degree from the City University of Hong Kong and is currently working as a postdoc researcher under the supervision of Prof. Liu CT. His research interests focus on the design, development, and application of high-strength steels.

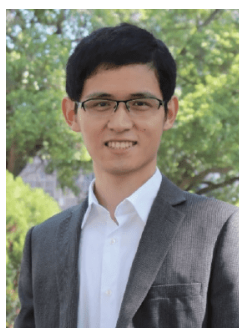

Zengbao Jiao received his $\mathrm{PhD}$ degree from the City University of Hong Kong under the supervision of Prof. Liu CT. He then worked as a postdoc fellow in the same group and in Prof. Christopher A. Schuh's group at Massachusetts Institute of Technology for another year. He is currently an assistant professor of The Hong Kong Polytechnic University. He specializes in advanced structural materials and $3 \mathrm{D}$ atom probe tomography.

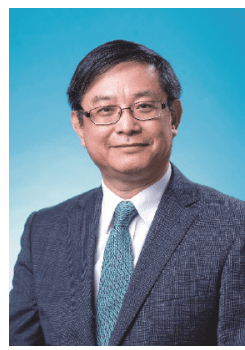

Jian Lu received his $\mathrm{PhD}$ in materials science and applied mechanics from the University of Technology of Compiegne. He is a member of the National Academy of Technologies, France, and currently the Vice-President (research and technology) of the City University of Hong Kong. He is well known for his contributions in the surface science and engineering as well as the processing and mechanical properties of advanced nanomaterials.

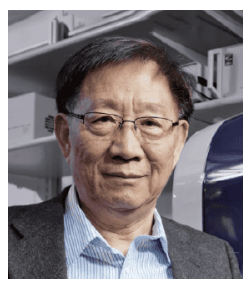

Chain Tsuan Liu obtained his PhD degree from Brown University. $\mathrm{He}$ is a member of the $\mathrm{Na}$ tional Academy of Engineering, USA, and the foreign member of the Chinese Academy of Engineering (CAE). He is currently the University Distinguished Professor at the City University of Hong Kong. He is among the world pioneers in the field of intermetallic alloys, bulk metallic glass, nanostructured steels, and advanced high temperature alloys.

\section{新型低碳纳米钢: 微观组织、机械性能与应用}

江豪㷊, 焦增宝 ${ }^{2}$, 吕坚 ${ }^{1,4,5}$, 刘锦川 ${ }^{1,3,4,5^{*}}$

摘要 新型低碳纳米钢已被开发且广泛应用于各种结构工程, 包括 桥梁、汽车和其他重要高强度应用, 如核电站反应堆压力容器. 纳 米钢的机械性能与应用, 在很大程度上取决于其微观组织. 通过控 制析出物的大小、数量密度、分布和类型, 可以生产出抗拉强度 高达 $2 \mathrm{GPa}$ 的纳米钢，同时保持 $10 \%$ 以上的良好拉伸延伸率及 $40 \%$ 的面积缩小率. 此外, 通过调控各种强化机制, 纳米钢可以避免回 火脆性, 从而具有优异的强度和低温冲击韧性. 通过添加适当的锰 $(\mathrm{Mn})$, 纳米钢可以在不牺牲其强度下 (屈服强度, YS 为 1100$1300 \mathrm{MPa}$; 极限抗拉强度, UTS为 1300-1400 MPa), 延展性提高3 倍(总拉伸延伸率, TE约为 $30 \%$ ). 更重要的是, 这些纳米钢有良好的 可加工性和可焊性. 本文全面综述了先进纳米钢的微观结构及其 性能关系. 此外, 本文对纳米钢的当前局限和未来发展进行了详细 的探讨和概述. 